\title{
Assessment of long-term measurements of particulate matter and gaseous pollutants in South-East Mediterranean
}

\author{
Petros Mouzourides ${ }^{1}$, Prashant Kumar ${ }^{2,3}$, Marina Neophytou K.-A. ${ }^{{ }^{*}}$ \\ ${ }^{1}$ Environmental Fluid Mechanics Laboratory, Department of Civil and Environmental \\ Engineering, University of Cyprus, Nicosia, Cyprus \\ ${ }^{2}$ Department of Civil and Environmental Engineering, Faculty of Engineering and Physical \\ Sciences (FEPS), University of Surrey, Guildford GU2 7XH, United Kingdom \\ ${ }^{3}$ Environmental Flow (EnFlo) Research Centre, FEPS, University of Surrey, Guildford GU2 \\ 7XH, United Kingdom
}

\begin{abstract}
This work examines long-term measurements of major criteria pollutants concentrations in an urban station in South-Eastern Mediterranean, in Nicosia - Cyprus, which is susceptible both to transboundary air pollution transport from Sahara-dust events as well as to evaporative transport of sea-sprays. The work investigates in particular the role of such multi-scale contributions in the urban air quality measurements, which are important considerations in the assessment of the effectiveness of any mitigation policies implemented by regulatory authorities. Attention is drawn in the regional-scale component of the particulate matter concentrations $\left(\mathrm{PM}_{10} ; \leq 10 \mu \mathrm{m}\right.$ in diameter) and its contribution in the local measurements. Hourly averaged data of $\mathrm{CO}, \mathrm{NOx}$ and $\mathrm{PM}_{10}$ concentrations as well as of meteorological parameters were collected from the Air Quality Monitoring Station (AQMS) of the University of Cyprus over a period of more than 5 years (2008-13) and were analysed. Scanning Electron Microscope (SEM) was used to identify chemical characteristics of $\mathrm{PM}_{10}$ and to attribute it to possible sources. A total of 321 days over the entire period were found to exceed the daily limit value of $50 \mu \mathrm{g} / \mathrm{m}^{3}$ for $\mathrm{PM}_{10}$ concentrations, which corresponds to $\sim 19 \%$ of the actual monitored time. Numerical simulations using the Dust REgional Atmospheric Model from Barcelona Supercomputing Center (BSC/DREAM) gave a strong indication that $\mathrm{PM}_{10}$ exceedances were associated with the high regional background dust concentrations during westerly winds. It was also found that despite the implementation of tighter regulations for vehicular and industrial emissions in Europe, the monthly average concentration values of criteria pollutants do not exhibit any falling trend.
\end{abstract}

Keywords: Urban air quality monitoring; Background pollutant concentration; Transboundary pollution; Pollution concentration exceedances; Nicosia-Cyprus; Scanning Electron Microscope

\footnotetext{
*Corresponding author: neophytou@ucy.ac.cy
}

Citation details: Mouzourides, P., Kumar, P., Neophytou M.K., 2015. Assessment of long-term measurements of particulate matter and gaseous pollutants in South-East Mediterranean. Atmospheric Environment 107, 148-165. [Online link] 


\section{Introduction}

The impact of air pollution on public health - especially of the airborne particulate matter (PM) - has been of major interest over the last decade to both the air quality management community and regulatory authorities (Heal et al., 2012; Middleton et al., 2008). The European Union Directive on Air Quality 2008/50/EC sets the general legislative framework on the air quality assessment in populated areas (see Supplementary Information, SI, Table S1Table S1).. This legislative framework has recommended target values for pollutants that are harmful to public health as well as to the environment and the built infrastructure (Kumar and Imam, 2013). These pollutants include carbon monoxide $(\mathrm{CO})$, nitrogen dioxide $\left(\mathrm{NO}_{2}\right)$, particulate matter $(\mathrm{PM})$ with diameter of $10 \mu \mathrm{m}$ or less $\left(\mathrm{PM}_{10}\right)$ and sulphur dioxide $\left(\mathrm{SO}_{2}\right)$. The prescribed standard values are intended to protect public health, including the health of "sensitive" populations such as asthmatics, children, and the elderly as well as to protect public welfare, including protection against decreased visibility (Huang et al., 2009), damage to animal health (Pope and Dockery, 2006), crops and vegetation (Bobbink et al., 1998), and buildings (Tiwary and Kumar, 2014).

Long-term local pollution concentration measurements are usually used and interpreted accordingly by Air Quality Regulatory authorities for the preposition of national or city-scale mitigation measures (as part of a national policy and strategy) for abidance to air quality limits. However such measurements may contain contributions from multi-scale (primarily non-local) causes; any such analyses for the design of strategies need to take into account that the effectiveness of any such proposed local measures will be determined by the relative contribution of the different (local versus non-local) causes. There are studies reporting that $\mathrm{PM}_{10}$ exceedances were associated with a high regional background concentrations (e.g. Goudie and Middleton, 2001, Charron et al., 2007). It is therefore crucial before any mitigation strategies are implemented in order for example to alleviate urban air quality effects such as respiratory and cardiovascular morbidity (Middleton et al., 2008) to account for the non-local contributions.

Meteorological conditions, emissions as well as the type of the urban built settings are some of the key factors that determine the air quality in urban areas. The meteorology is known to exhibit strong annual and seasonal variations modulated by changes of the large scale atmospheric circulation (Seinfeld and Pandis, 2012). The resulting air flow and in turn the particular pollution dispersion field within urban settings is then determined by characteristics of the buildings and street-canyons (e.g. Neophytou et al., 2014, Panagiotou et al., 2013; Neophytou et al, 2011; 
Kumar et al., 2008). Emissions, that originate from local (national) sources of different types, change from year to year as a result of changes in the anthropogenic activities that emit pollutants; for example due to socio-economic reasons such as increased wood burning for heating due to the economic crisis (Saffari et al., 2013). Pollution sources are also related to traffic, industrial and domestic anthropogenic activities, which could be local or elsewhere. On the other hand, sinks are mainly due to chemical reactions or depositions (e.g. dry and wet). Usually emissions of pollutants due to local sources significantly affect the air quality in an area. However, background concentrations of pollutants in an urban environment may play a key role in determining the urban air pollution field. At the same time, the contribution of chemical reactions towards air pollution depends on a number of factors, primarily including the reaction time-scale and its relative comparison with the diffusion time scale (Neophytou et al, 2004; Neophytou et al., 2005).

South-Eastern Mediterranean is a region particularly susceptible to such mutli-scale contributions. Viana et al. (2013) report a significant impact of natural episodes (e.g. African dust) on the air quality in Southern and Western Europe, while Michaelides et al. (1999) report that dust events are commonly observed during the spring season over the Eastern Mediterranean. Furthermore, a number of studies (e.g. Goudie and Middleton, 2001; Gerasopoulos et al., 2006; Koulouri et al., 2008; Viana et al., 2013) investigated long-term monitoring data from stations in Southeast Europe to identify the main sources of $\mathrm{PM}_{10}$. However, to date, no such long-term assessment of both the $\mathrm{PM}_{10}$ and gaseous pollutants concentration levels (such as $\mathrm{CO}$ and $\mathrm{NO}_{\mathrm{x}}$ ) has been conducted in the region over Cyprus in order to understand how these concentration levels are affected by the prevailing meteorological conditions.

In this paper we report a long-term assessment of $\mathrm{NO}_{\mathrm{x}}, \mathrm{CO}$ and $\mathrm{PM}_{10}$ concentrations measured in South-Eastern Mediterranean, at an urban station in Nicosia - Cyprus, with particular attention in the $\mathrm{PM}_{10}$ concentrations and the multi-scale (and multi-kind) contributions contained therein. Such an assessment has direct implications for the design of mitigation strategies. Beyond the local anthropogenic sources (primarily traffic and industrial), $\mathrm{PM}_{10}$ are known to originate also from i) dust events, that mainly refer to the wind-blown transport of natural particles from dryarid regions, in this case from the African Sahara desert, ii) sea sprays which are finely dispersed Particulate Matter (PM) emitted from the sea surface, produced via the bubble-bursting processes 
leading to the production of film and jet drops, and iii) the local natural mineral dust due the local rich geological formations of the island. Measurements of the $\mathrm{NO}_{\mathrm{x}}, \mathrm{CO}$ and $\mathrm{PM}_{10}$ concentrations as well as of the meteorological conditions in Nicosia collected using the Air Quality Monitoring Station (AQMS) of University of Cyprus over a period of 69 month were assessed. A statistical analysis was performed and provided the most significant conditions and parameters that affect the air quality in the area. Moreover, samples from NOx AQMS-analyzer filters were examined using a Scanning Electron Microscope (SEM) in order to obtain the elemental composition as well as to understand the morphology of the airborne particles and therefore to identify their possible sources. Numerical simulations using the Dust REgional Atmospheric Model from Barcelona Supercomputing Center (BSC/DREAM) were also used to examine possible effects of regional scale flow patterns on dust concentrations. The influence of multi-scale meteorology on pollutant concentrations and the trend of criteria pollutants is crucial in the focus of this study in order to provide insight in the development of appropriate regulatory tools for urban air quality.

\section{Methodology}

\subsection{Site description}

Continuous monitoring data were collected in the South-East Mediterranean basin in the period from $1^{\text {st }}$ April 2008 to $31^{\text {st }}$ December 2013 using the Air Quality Monitoring Station (AQMS) of the University of Cyprus (UCY); the station is located at the South East (SE) outskirts of Nicosia city that is situated in the middle of the island. The initial location of the station was in the proximity of the UCY Student Halls Campus and next to a busy road with a traffic light at about $250 \mathrm{~m}$ away controlling a T-junction (Fig. 1). Therefore, the station measurements during that period were considered as urban roadside measurements. On $12^{\text {th }}$ April 2011, the station was relocated $1 \mathrm{~km}$ away from the previous location of the station in the North East (NE) direction (Fig. 1); it is considered as a rural background location, because the surrounding area is open with agricultural fields and the small road located $30 \mathrm{~m}$ in front of the station has very sparse road traffic.

Any construction activities taking place during the monitoring period were also noted, since they may affect the air quality of the surrounding area (Kumar and Morawska, 2014). Such construction and road works were in progress in the UCY New Campus area during 2008. 


\subsection{Instrumentation and data collection}

All continuous monitoring data were reported on hourly average intervals over the period from 2008 to 2013. This data streaming was performed using WinAQMS and WinCollect softwares (Ecotech 2007). WinAQMS software was also used for calibration, maintenance and monitoring of instruments performance on a weekly-basis during the study period. AQMS station measures meteorological parameters such as wind speed (WS), wind direction (WD), ambient temperature (AT), barometric pressure (BP), relative humidity $(\mathrm{RH})$, rain fall (RF) and solar radiation (SR). Concentration measurements of nitrogen monoxide (NO), nitrogen dioxide $\left(\mathrm{NO}_{2}\right)$, nitrogen oxides $\mathrm{NO}_{\mathrm{x}}\left(=\mathrm{NO}+\mathrm{NO}_{2}\right), \mathrm{PM}_{10}$ and $\mathrm{CO}$ were also taken; the samples for these measurements were at $\sim 3 \mathrm{~m}$ height above ground level.

A Model48i-analyzer and Model 42i (Thermo Fisher Scientific Inc.) were used to carry out measurements of $\mathrm{CO}$ and $\mathrm{NO}_{\mathrm{x}}$ concentrations respectively. Sampling rate of $\mathrm{NO}_{\mathrm{x}}$ and $\mathrm{CO}$ analyzers is $10 \mathrm{sec}$, and once the period of 60 minutes has elapsed, WinAQMS calculates the hourly-average value of $\mathrm{NO}_{\mathrm{x}}$ and $\mathrm{CO}$ concentration by using the $10 \mathrm{sec}$ data values. In a same way, WinAQMS calculates the hourly-average value for all instruments and sensors. Finally an ambient particulate monitor, a Tapered Element Oscillating Microbalance (TEOM; 1400ab; Thermo Fisher Scientific Inc.) was used to measure gravimetrically the $\mathrm{PM}_{10}$ levels.

Statistical values of the mean and standard deviation are shown in Table 1 and were calculated over the actual collected measurements and not over the entire possible data encapsulated in the time period of observation. Specifically, the measurements contained 40224, 36607 and 40907 samples of $\mathrm{NO}_{\mathrm{x}}, \mathrm{CO}$ and $\mathrm{PM}_{10}$ hourly measurements respectively, which corresponds to $\sim 80 \%$, $73 \%$ and $81 \%$ of possible data over the entire period, respectively. It is also noted that from the above number of records, a total of 34368 hourly data correspond to simultaneous hourly measurements of $\mathrm{NO}_{\mathrm{x}}, \mathrm{CO}$ and $\mathrm{PM}_{10}$ concentrations. Any missing values that exist in the dataset (i.e. gaps that appear in time series plots) are either because of maintenance or calibration processes on instruments or instruments being out of service due to some failure e.g. a powercut.

\subsection{Analysis}

The collected hourly data were analysed using Matlab $^{\circledR}$ (R2012b v.8.0) and $\mathrm{R}^{\circledR}$ (v.2.13.1) statistical software. These data is presented either in the form of a time-series plot or wind rose. 
The red vertical line in the time series plots marks the time of relocation of the AQMS station from its initial position to its current one in the University Campus. In the present study, the frequency distribution was deduced for the wind speed and wind direction data in order to study the dominant-prevailing winds regime and its seasonal variability as well as the levels of pollutant concentrations in Nicosia area. PCA was applied on the 69-month dataset in order to identify and quantify the overall contribution of the most important meteorological parameters on the pollutant concentrations (Krzanowski, 2000). In the PCA each principal component (PC) is a linear combination of the original variables, and all PCs are orthogonal to each other, so there is no redundant information and explain as much as possible the total variation or almost the total variation of the original dataset (total variation is the sum of the variance of each PC). In this paper, PCA was performed using the SPSS software. Monthly means of criteria concentrations were examined in terms of cumulative sums (CUSUM) with the aim to reveal changes or shifts in the trend line and is based on calculating the cumulative sums (Montgomery, 2007). It takes care of the shift in the measurements from the mean of the process and if a point exceeds the control limits of upper decision boundary (UDB) and lower decision boundary (LDB) this point is reported as a change point. The specification of appropriate parameter values that are required within the method was done according to recommendations by Montgomery (2007). The change-point method was first adopted in urban air pollution concentration time series analysis by Carslaw et al. (2006) for assessing the impact of major policy changes on air pollutants at Marylebone Road, London (UK).

\subsection{Scanning Electron Microscope}

The Scanning Electron Microscope (SEM) method provides information on the morphology and chemical composition of samples of composites. Moreno et al. (2003) have investigated the weaknesses and limitations of the characterisation of particles using SEM, but confirm that the SEM provides key information on surface morphology and elemental composition of particles collected on filters. Our analysis was performed at the Electron Microscopy Facility of the MicroStructural Studies Unit (MSSU) of the University of Surrey, UK. SEM (model: JEOL JSM-7100F), which is a high resolution microscope.

Polytetrafluoroethylene (PTFE) filters used in the NOx analyzer of the AQMS were collected and analysed. Eight samples $(0.5 \mathrm{~cm}$ is the size of each sample) from three PTFE filters as well a clean PTFE filter were studied. The SEM results of a clean PTFE filter are used to derive the

Citation details: Mouzourides, P., Kumar, P., Neophytou M.K., 2015. Assessment of long-term measurements of particulate matter and gaseous pollutants in South-East Mediterranean. Atmospheric Environment 107, 148-165. [Online link] 
interpretation of the used-filter results. The first filter used by the analyzer was from the $25^{\text {th }}$ October 2013until the $10^{\text {th }}$ November 2013; the second one used was from the $10^{\text {th }}$ November 2013 until the $26^{\text {th }}$ January 2014 and finally the third one was used from the $26^{\text {th }}$ January 2014 until the $12^{\text {th }}$ February 2014. The pores size of these filters is $5 \mu \mathrm{m}$. Before carrying out any experiment with the SEM, care was taken so that there is no moisture on the samples because the water would vaporize in the vacuum. PTFE filters were flat-mounted (using epoxy-resin) over a steel SEM stubs. Furthermore, samples were covered with a thin layer of conductive material like gold $(\mathrm{Au})$ aiming the sample to be conductive. Metal coating of the samples prevent charging of the samples with an electron beam in high vacuum and high voltage conditions as well increase the signal-to-noise ratio for better results. In our case, we set the microscope working distance at $10 \mathrm{~mm}$, the image pixel size $0.12 \mu \mathrm{m}$, the accelerating voltage of $10 \mathrm{kV}$ and the magnification 1,000x. For greater accuracy of particles' elemental characterization, each sample was in the SEM chamber for about 3 hours.

\subsection{Forecasting model for regional dust loads}

Predictions from the forecasting Dust Regional Atmospheric Model at Barcelona Supercomputing Center (BSC/DREAM) by Nickovic et al. (2001) were used in order to identify the qualitative correlation of regional background concentrations with the $\mathrm{PM}_{10}$ exceedances.. In this paper, modelled data and images have been specifically taken from the BSC-DREAM8b (http://www.bsc.es/projects/earthscience/BSC-DREAM/) which solves numerically the Eulertype mass partial differential equation and reports aerosol dust load profiles on a uniform spatial grid. The dust model takes into account all major processes of dust life cycle, e.g. dust production, horizontal and vertical diffusion, advection, wet and dry deposition along with the effects of the particle size distribution on aerosol dispersion. The model is very simple to use since all that is required to get results is to define the coordinates and the period of interest on the model's website.

\section{Results and Discussion}

\subsection{Overall summary of meteorological data}

The overall meteorological and air quality data collected over the entire period of $1^{\text {st }}$ April 2008 until 31 ${ }^{\text {st }}$ December 2013 is presented in Fig.2, with their corresponding frequency distributions shown in histograms in Fig.3. Histograms illustrate the variability of the hourly values of the meteorological parameters. As seen from Fig.3a, ambient temperature varied 
generally between 10 and $30{ }^{\circ} \mathrm{C}$ during the measurement period. The temperature exceeds the 40 ${ }^{\circ} \mathrm{C}$ in a few extreme cases $(0.01 \%$ density). It is also important to mention that, for the study area, average temperature differences between day and night were found to be $\sim 12{ }^{\circ} \mathrm{C}$. The dominant wind speed values were found to be between 0.5 to $1.5 \mathrm{~m} / \mathrm{s}$. In addition, Fig.3d shows that the rainfall $(\mathrm{RF})$ is poor since its values are never greater than $0.0025 \mathrm{~mm} / \mathrm{h}$. In agreement with temperature results, Relative Humidity (RH) exhibit wide variability. However, its distribution is shifted to high values from 75 to $90 \%$. The high relative humidity in combination with poor rainfall during all seasons highlights also some special climatic conditions of the area. Table 1 summarizes the yearly averaged values of all the recorded atmospheric parameters (barometric pressure, relative humidity, rainfall, atmospheric temperature, solar radiation and wind data), plus the yearly-averaged values of air quality parameters $\left(\mathrm{NO}_{\mathrm{x}}, \mathrm{CO}\right.$ and $\left.\mathrm{PM}_{10}\right)$.

\subsection{Concentration assessment of criteria pollutants}

Overall,, criteria pollutants concentrations measurements over a period of 69 months in Nicosia, were used to study the different sources and factors (e.g. meteorological parameters) that affect their levels. The average values of NOx and CO hourly recorded values for the whole period were $13.6 \pm 21.5 \mathrm{ppb}$ and $1.5 \pm 1.1 \mathrm{ppm}$ respectively. The average value of $\mathrm{PM}_{10}$ concentration for the entire period is $32.4 \pm 45.6 \mu \mathrm{g} / \mathrm{m}^{3}$. A more detailed study on $\mathrm{PM}_{10}$ concentrations showed a total of 321 days exceeding the daily limit value of $50 \mu \mathrm{g} / \mathrm{m}^{3}$ especially during spring and autumn seasons. This number of exceedances of the $\mathrm{PM}_{10}$ concentrations during these seasons, is consistent with results reported by Gerassopoulos et al. (2006) for the region of Crete.

\subsection{The effect of meteorology on concentrations}

In order to identify and quantify the contribution of the most important meteorological parameters in relation to the pollutant concentrations, PCA was applied to a dataset composed by three pollutants $\left(\mathrm{NO}_{\mathrm{x}}, \mathrm{CO}\right.$ and $\left.\mathrm{PM}_{10}\right)$ and seven meteorological parameters (WS, WD, AT, BP, $\mathrm{RH}, \mathrm{RF}$ and SR). Interpretation of the PCs is based on finding which variables are most strongly correlated with each component according to PC value. Table 2 presents the eigenvalues and loadings of PC for the studied dataset. Only loadings with absolute values greater than 0.5 of the maximum value (Jolliffe, 2002) are selected for the PC interpretation (in bold font). The studied dataset yields four PCs, which explain the $65 \%$ of its total variance.

Citation details: Mouzourides, P., Kumar, P., Neophytou M.K., 2015. Assessment of long-term measurements of particulate matter and gaseous pollutants in South-East Mediterranean. Atmospheric Environment 107, 148-165. [Online link] 


\section{First principal component (PC1)}

The first PC correlates most strongly with AT, RH, SR, WS and BP. Therefore PC1 can be viewed as a measure of meteorology. Also, PC1 shows that when there is an increase in AT values, at the same time high values of SR and WS are observed. On the other hand, high values of AT yield reduction on BP and RH values (because of negative sign).

\section{Second principal component (PC2)}

PC2 shows an association between $\mathrm{CO}, \mathrm{PM}_{10}$ and WD. The appearance of this cluster between negative loading of $\mathrm{CO}$ and positive loading of $\mathrm{PM}_{10}$ give a strong indication that PC2 describes the effect of automobiles traffic, under the influence of WD. In addition, the clustering of CO, $\mathrm{PM}_{10}$ pollutants can be explained by the fact that these pollutants have similar lifetime and temporal scale (see SI Fig. S1 and Table S2). The negative sign of WD loading is not important because this is not a continuous variable. This variable has a range of values between $0^{\circ}$ and $360^{\circ}$.

\section{Third principal component (PC3)}

This PC exhibits a high association between WS, WD and CO concentrations. The cluster between these three variables depicts the strong influence of wind speed and wind direction on $\mathrm{CO}$ concentrations. In fact, this relationship is inversely proportional (i.e. when strong winds are observed, a decrease in pollutants concentrations is also observed). The reason is likely due to the pollutant dispersion, where locally strong winds disperse the pollutants and thereby reduce ambient concentration.

\section{Fourth principal component (PC4)}

PC4 considers NOx concentration as a separate PC in the environment of Nicosia. Although WD has a loading value of 0.47 , which is lightly below the threshold of 0.5 , indicating that the WD affects NOx concentrations.

The results of PCA reveal underlying relationship between pollutant concentrations and wind speed and direction. PCA assumes a linear relationship between the measurement variables. This relationship, using PCA, was also found to hold for the studies in Athens (Statheropoulos et al.,1998) Kuwait City (Abdul-Wahab et al.,2005). The above results suggest a study of the effect of wind speed and direction on pollutants concentrations as a next step. 


\subsection{Yearly and seasonal variability of pollutants concentrations}

\subsubsection{Yearly variations}

Fig. 2(f-h) shows the time series of $\mathrm{NO}_{\mathrm{x}}, \mathrm{CO}$ and $\mathrm{PM}_{10}$ and Table 1 summarizes the yearly averaged values (with their corresponding standard deviation) of the three criteria pollutants. The highest annual average values for $\mathrm{NO}_{\mathrm{x}}$ were observed during 2010 to be $18.0 \pm 21.0 \mathrm{ppb}$ and the lowest values were observed during 2012 to be $11.1 \pm 13.9 \mathrm{ppb}$. Regarding $\mathrm{CO}$ measurements, it must be noted that there is a relatively high proportion of missing concentration data in 2008 and in 2013 (25\% and 28\% respectively) and therefore the year exhibiting the higher or lower CO concentration cannot be concluded confidently. However the year 2010 showed the highest annual average value of $\mathrm{CO}$ as $2.0 \pm 0.6 \mathrm{ppm}$. The atmospheric pollution levels reported for other Mediterranean cities (Kanakidou et al., 2011) provide $\mathrm{NO}_{\mathrm{x}}$ concentrations levels to range between $49.9 \pm 22.0$ and $197.5 \pm 14.1 \mathrm{ppb}$, while CO concentration to be between $1.9 \pm 0.6$ and $6.2 \pm 1.2 \mathrm{ppm}$. For $\mathrm{PM}_{10}$, the annual average in 2008 was found to be $67.44 \pm 70.55 \mu \mathrm{g} / \mathrm{m}^{3}$; it is noted that during that year construction works were carried all around in the broader area of the University Campus. The lowest average annual concentration for $\mathrm{PM}_{10}$ $\left(11.48 \pm 22.80 \mu \mathrm{g} / \mathrm{m}^{3}\right)$ was recorded during 2010. Kanakidou et al. (2011) reported annual average $\mathrm{PM}_{10}$ levels that reached $75.5 \pm 27.5 \mu \mathrm{g} / \mathrm{m}^{3}$ (for June 1999 - May 2000) in Athens $\mathrm{PM}_{10}$ on a busy central street. Therefore, comparison of the above results with the results in an urban area in S-E Mediterranean shows that air pollution level at the outskirts of Nicosia is moderate.

\subsubsection{Seasonal variations}

The distribution of wind direction and speed over the whole period of measurements is best represented using the wind rose diagrams. Fig. 4 presents the hourly frequency distribution during the measurement period. The frequency distribution function is indicated by the concentric circles and the wind speed frequency distribution for a particular wind sector is given by the radial dimension of the radius. The centre of each plot represents a wind speed of zero, which increases radially outwards. This figure indicates that winds in Nicosia exist within the wind sectors of $270.0 \pm 22.5^{\circ}$ (West; W) and $292.5 \pm 22.5^{\circ}$ (West to North-West; W-NW) for most of the time. Furthermore, strong winds above $4.0 \mathrm{~m} / \mathrm{s}$ occur mainly from the same sectors. The overall probability of occurrence of strong winds on these sectors is approximately $6 \%$. 
The annual wind speed frequency distribution - using hourly average values - is presented in Fig. 5. It is observed that $\mathrm{W}$ and W-NW wind directions dominate the period of 2008 to 2013, except in 2011 when West and West to South-West (W-SW) are the predominant wind directions. As shown in Fig. 5, during the year of 2012, winds in North-West (NW) and W-SW directions are also present. The frequency of occurrence of NW and W-SW wind directions in 2012 is $11 \%$ and $12 \%$, respectively. To look further into the wind direction characteristics in the city of Nicosia, a frequency distribution analysis was applied for the four seasons in Cyprus: spring (March, April, May), summer (June, July, August), autumn (September, October, November) and winter (December, January, February). Fig. 6 shows that SW winds dominate the winter season, while a small frequency of North-East (NE) and NW winds is also present, as indicated by a small peak in the frequency distribution. In addition,Fig. 6 Fig. 6 shows that spring and summer seasons exhibit similar frequency distribution. During these seasons $\mathrm{W}$ and $\mathrm{WN}-\mathrm{W}$ wind sectors are predominant. On the other hand, the autumn season shows a wide range of wind directions. However, the predominant wind sectors during the autumn season are from SW to NW, with most prominent winds from the N sector (10\% frequency of occurrence).

Apart from the wind data, seasonal average values of other meteorological parameters such as AT, WS, SR and $\sigma_{\theta}$ (the standard deviation within the hourly wind direction mean measurement) are used to characterise the atmospheric stability (see SI Table S3). Table 3 shows that during spring and autumn the atmosphere in the area, according to Pasquill (1961), is very unstable while during the winter and summer, the atmosphere is unstable. Moreover, the precipitation in the area is minimal and consequently the contribution of wet deposition due to rainfall is considered negligible. Table 3 summarizes the most important factors that influence pollutants' concentrations in the study area. Apart from the meteorological parameters (which determine the atmospheric stability and therefore the atmospheric dispersion), traffic also affects the level of pollutants concentration. The traffic in the area is estimated to be fairly high during the seasons of autumn, winter and spring, while relatively low during the summer season due to the University closure for the summer holidays of students who are the main road users.

Table 4 presents the seasonal average values of $\mathrm{NOx}, \mathrm{CO}$ and $\mathrm{PM}_{10}$. The highest seasonal average value for NOx was observed to be in the winter season, equal to $19.95 \pm 23.36 \mathrm{ppb}$, while the lowest seasonal average was observed for the summer period and found to be $8.09 \pm 26.93$ ppb. For the CO concentrations, the highest seasonal average value was found to be for the 
winter season equalling $1.91 \pm 1.18 \mathrm{ppm}$, while the lowest seasonal average value $(1.39 \pm 1.24$ ppm) was observed during autumn season. On the contrary, the highest concentrations of $\mathrm{PM}_{10}$ were measured during the seasons of spring and autumn where the predominant wind directions are from the WN-W sector.

\subsection{Trends of monthly and daily mean concentrations}

The data obtained during the period between $1^{\text {st }}$ April 2008 and $31^{\text {st }}$ December 2013 were used to investigate the trend of the daily and monthly-averaged concentration of studied pollutants. Overall, high concentrations of $\mathrm{PM}_{10}$ were observed during the year of 2008, mainly due to the construction works taking place throughout that year at the University Campus facilities within a radius of less than $500 \mathrm{~m}$ from the AQMS location. Table 1 shows CO exhibiting low concentration values in 2008 and 2012 compared to the rest of the years; this is due to missing measurements during the winter and part of spring season. According to Seinfeld and Pandis, (2012) CO pollutant concentrations exhibit higher values during winter and spring seasons compare to autumn and summer seasons.

At first, daily mean values of the criteria pollutants concentrations were used in order to study their temporal trend in the area of Nicosia. The results of CUSUM technique are not presented in this paper. The large number of change-points on daily trend can hardly be explained because usually very local anthropogenic activities (local construction activities or a large number of traffic volume which occur for a short time) can hardly be track and explain.

Fig. 7a, c and e present the monthly mean values of $\mathrm{NOx}, \mathrm{CO}$ and $\mathrm{PM}_{10}$ concentrations, respectively. These plots show a considerable seasonal variation in the monthly concentration of all species. Despite that measurements were taken in a period of a rapidly growing area, Fig. 7 illustrates that $\mathrm{NOx}, \mathrm{CO}$ and $\mathrm{PM}_{10}$ concentrations do not exhibit substantial falling trend. A visual inspection of these plots does not show abrupt changes or shift on concentrations trend. Therefore the application of CUSUM technique was used to investigate the monthly-mean concentration values and to reveal any such changes. It must be stressed that before the CUSUM analysis, missing values were interpolated using nearest neighbour interpolation. Fig. 7Fig. 7b, d and $\mathrm{f}$ present the calculated CUSUMs for NOx, $\mathrm{CO}$ and $\mathrm{PM}_{10}$ concentrations, respectively. The horizontal axis represents the months of analysis where number 1 stands for April of 2008 and number 69 stands for December 2013. These results depict that a single change-point was 
detected for concentration of all species on April 2011 (number 37). Therefore the single changepoint occurs on April 2011, indicating the relocation of AQMS station.

The CUSUM analysis of NOx concentrations yield in two more single change-point, however these single change-points depict long periods where the analyzer was out of service. The CUSUM analysis of $\mathrm{CO}$ concentrations reveals that there is an abrupt reduction in $\mathrm{CO}$ due to seasonal cycle in November 2009 (Derwent et al., 1998). The single change-point shown in CO concentrations in September 2013 is due to the fact that the CO analyzer was out of service for a long time. On the other hand, the CUSUM analysis for $\mathrm{PM}_{10}$ reveals the month when construction works in the university area were completed; Fig. $7 \mathrm{f}$ shows $\mathrm{PM}_{10}$ concentration to exhibit a downward trend after March 2009.

Our temporal trends of $\mathrm{NOx}$ and $\mathrm{PM}_{10}$ concentrations are found to be similar with other results reported by Harrison et al. (2008) where in the last decade, NOx and $\mathrm{PM}_{10}$ concentrations are observed not to exhibit any falling trend in Europe, even if exhaust emissions standards and stationary sources regulations become tighter (Harrison, 2004; Kumar et al., 2014b). Therefore, the question being raised is whether current knowledge on source apportionment of criteria pollutants is sufficient and whether European agencies are provided with appropriate tools for the protection of human health.

\subsection{Concentration exceedances}

The regulations of the European Union Directive on Air Quality 2008/50/EC prescribes limit values for $\mathrm{CO}$ and $\mathrm{PM}_{10}$ as well as $\mathrm{NO}_{2}-$ not for $\mathrm{NO}$ or NOx (see SI, Table $\mathrm{S} 1$ ). $\mathrm{NO}_{2}$ concentrations are deduced by subtracting the NO concentration measurements from NOx ones. Statistical analysis on pollutants concentrations reveals that $\mathrm{NO}_{2}$ and $\mathrm{CO}$ concentrations are significantly below the limit values of EU Directive and the maximum hourly concentration of $\mathrm{NO}_{2}$ is $\sim 50 \%$ less than the Directive limit of $105 \mathrm{ppb}$. The maximum hourly measured concentration of $\mathrm{CO}$ is $8.9 \mathrm{ppm}$, thus any rolling 8-hour average in a day will be less than the corresponding limit value of $11.6 \mathrm{ppm}$. Therefore, it can be concluded with confidence that there are no exceedances of the Directive limits for $\mathrm{NO}_{2}$ and $\mathrm{CO}$ concentrations during the measurement period.

Citation details: Mouzourides, P., Kumar, P., Neophytou M.K., 2015. Assessment of long-term measurements of particulate matter and gaseous pollutants in South-East Mediterranean. Atmospheric Environment 107, 148-165. [Online link] 
On the contrary, a large number of $\mathrm{PM}_{10}$ exceedances have been observed over the measurement period as depicted in Fig. 8c; specifically, the $\mathrm{PM}_{10}$ daily limit value of $50 \mu \mathrm{g} / \mathrm{m}^{3}$ is violated 171 times in 2008 and 64 times in 2009. Exceedances of the daily limit value for $\mathrm{PM}_{10}$ were also observed in 2011 (34 times) and 2012 (24 times). It is worth noting that the number of missing measurements reached 503 in 2011 and 2,100 in 2013 (see Table 5). Missing measurements were either due to maintenance/instrument calibration processes or due to instruments being unexpectedly out of service (e.g. due to unexpected power-cuts).

Our findings are also in agreement with results presented by Viana et al. (2013) for the region of Cyprus, since daily $\mathrm{PM}_{10}$ exceedances in 2008 ranged between 60 and 90, while in 2009 these exceedances reached more than 90. As seen in Table 1, annual average for $\mathrm{PM}_{10}$ in the year 2008 was $67.44 \pm 70.55 \mu \mathrm{g} / \mathrm{m}^{3}$ where this value does not meet the annual limit value of EU Directive value of $40 \mu \mathrm{g} / \mathrm{m}^{3}$ (see SI, Table S1). As also stated earlier, the qualitative result (as pattern) of the $\mathrm{PM}_{10}$ exceedances is also consistent with results reported by Gerassopoulos et al. (2006) for the region of Crete.

Fig. 8 shows the average concentration values of NOx, CO and $\mathrm{PM}_{10}$ in each sector (light blue colour) and the lower concentrations (red colour). It can be inferred that concentrations depicted in red colour correspond to the background concentration of the study area. According to the above results, it has been estimated that the background concentrations (red values), constitute the $\sim 2.6 \%$ (WN-W) to $\sim 8.5 \%$ (East) of the average NOx concentration (blue values). In the case of $\mathrm{CO}$, the background concentrations are the $2.6 \%(\mathrm{WN}-\mathrm{W})$ to $7.1 \%(\mathrm{NE})$ of the average concentration of $\mathrm{CO}$ while the corresponding percentage of background $\mathrm{PM}_{10}$ concentration varies between $2.1 \%(\mathrm{WN}-\mathrm{W})$ to $11.9 \%(\mathrm{~S})$. The high concentrations for $\mathrm{NO}_{2}$ and $\mathrm{CO}$ are coming from the SW sector (24.33 ppb and $1.98 \mathrm{ppb}$ for each pollutant respectively), while the higher concentration of $\mathrm{PM}_{10}\left(44.02 \mu \mathrm{g} / \mathrm{m}^{3}\right)$ is coming from S-SE sector. The disadvantage of these polar plots is that they do not give any information about the frequency of occurrence of these values.

In order to identify the presence and characteristics of different sources of air pollution, bivariate polar plots were used. These plots are constructed by partitioning wind speed/direction data with the same values - and their corresponding concentration data - into wind speed/direction bins (boxes). Then (for each bin) the mean concentration value is calculated. For better visualization, 
and quick directional information of potential sources, adjacent bins with the mean concentration values, are smoothed by using smoothing techniques (see Carslaw and Rotkins, 2012 for details). Plots such as those shown in Fig. 9 represent continuous concentration surfaces that use smoothing techniques. Therefore colour bars should not be interpreted as measurement values. The conclusions drawn from Fig. 9a-c is that the concentration pattern between the three pollutants is different. In the case of $\mathrm{NO}_{2}$ high concentrations are observed when winds occur along NW-SE direction and the wind speed is smaller than $2 \mathrm{~m} / \mathrm{s}$. Additional contribution on $\mathrm{NO}_{2}$ concentrations is observed when winds occur along $\mathrm{SW}$ sector with wind speed and the wind speed up to $3 \mathrm{~m} / \mathrm{s}$. Fig. $9 \mathrm{~b}$ shows that $\mathrm{CO}$ high concentrations were observed in almost all directions with either large or small wind speeds.

Table 6 summarizes both the anthropogenic and natural processes that exist in the surrounding area and affect $\mathrm{PM}_{10}$ concentrations. Apart from traffic, which is the main anthropogenic activity, agriculture processes may also have a contribution to $\mathrm{PM}_{10}$ concentrations since the areas in NE and SE regions are agricultural. Fig. 9c shows that high $\mathrm{PM}_{10}$ concentrations are observed mainly when winds blow along NW sector and the wind speed is larger than $6 \mathrm{~m} / \mathrm{s}$ at this time. Moreover, high $\mathrm{PM}_{10}$ concentrations are measured when winds occur along the East North-East (E-NE) and South South-East (S-SE) sectors, and wind speeds are larger than $6 \mathrm{~m} / \mathrm{s}$. As seen in Fig. 1, $\mathrm{PM}_{10}$ concentrations originating from the E-NE and S-SE sectors appear to be arising from the agricultural processes (e.g. field plowing).

While such a representation of the concentration measurements is very useful and can lead to important conclusions, care should be taken in interpreting such representations as this can be misleading at the same time. For example, bivariate polar plots of Fig. 9a-c do not take into account the frequency of observation of each measurement and how these measurements affect the overall mean concentration (Carslaw and Beevers, 2013). Smoothed surfaces in Fig. 9d-f are useful since they provide an indication of the weighted concentration (i.e. multiplied by the frequency of occurrence, bin frequency, divided by the total frequency) in order to give an improved and more representative indication of the conditions that dominate the overall mean concentration. The weighted bivariate polar plots are shown as a continuous-smoothed surface and present the concentration data in polar coordinates for the purpose of possible source identification. As a result, Fig. 9d-f show that all three pollutants were derived from the same local road traffic sources from the NW sector; in addition, they indicate that the main emissions 
of $\mathrm{PM}_{10}$ are local (small wind speeds), stemming mainly from the NW sector. However, as it was shown in Fig. 9a-c, exceedances or large concentration values were observed when dominant winds are coming from NW, E-NE and S-SE sectors with high wind speed. Therefore what is considered necessary is to use both types of plots for understanding the pollutants dispersion in the study area. Quantification of the exact proportion amongst the concentration due to local sources and regional-background concentrations require dedicated detailed studies, which is beyond the scope of current work.

The above results allow to conclude that concentrations of $\mathrm{NO}_{2}, \mathrm{CO}$ and $\mathrm{PM}_{10}$ are primarily due to local road traffic (see Fig. 10). The concentrations of $\mathrm{NO}_{2}$ and $\mathrm{CO}$ do not exceed the limit values of EU Directive, whereas $\mathrm{PM}_{10}$ concentrations exhibit exceedances. High $\mathrm{PM}_{10}$ concentrations values were observed when dominant winds are coming from NW, E-NE and SSE sectors with wind speed over about $6 \mathrm{~m} / \mathrm{s}$.

\subsection{Elemental composition of airborne particles}

Fig. 11a presents the morphology of a clean (unused) PTFE filter, which can be characterized as amorphous or heterogeneous structure, where black holes are depicting the porosity of the filter. Fig. 11b-f show SEM images of three filters that were used during different time periods (see details in Section 2.4). On these filters there are particles with smaller dimensions of $10 \mu \mathrm{m}$, whilst in a red circle are shown particles with larger dimensions than 10 $\mu \mathrm{m}$. SEM images confirmed, first of all, that airborne particles are found in different shapes and dimensions.

SEM analysis also provided important insights about the chemical composition of the samples. First, the column in Table 7 presents the elemental composition of the clean filter. Elementalcomposition data of the clean filter is important for the interpretation of used-filter results, since the elements found in the clean-filter analysis may also be found on used-filter SEM results, and therefore these elements should not be attributed to the pollutants. The analysis of clean filter showed the existence of $\mathrm{C}$ and $\mathrm{F}$ elements (in fact the PTFE filters are made of these materials), the existence of $\mathrm{Au}$ elements (the coating material of samples) as well the existence of the $\mathrm{Fe}$ element (substrate disk material). Therefore these five elements can be considered as "background" elements and were ignored in the SEM analysis of the used filters. The used-filter analysis showed that there are 11 elements (specifically: $\mathrm{Al}, \mathrm{Ca}, \mathrm{Cl}, \mathrm{In}, \mathrm{K}, \mathrm{Mg}, \mathrm{N}, \mathrm{Na}, \mathrm{O}, \mathrm{Pb}$ and

Citation details: Mouzourides, P., Kumar, P., Neophytou M.K., 2015. Assessment of long-term measurements of particulate matter and gaseous pollutants in South-East Mediterranean. Atmospheric Environment 107, 148-165. [Online link] 
$\mathrm{Rb}$ ) and some of them in an oxide form due to the presence of O. Matti Maricq (2007) summarizes the chemical properties of PM from diesel vehicle exhaust and reports that $\mathrm{Al}, \mathrm{Ca}$, $\mathrm{Cl}, \mathrm{K}, \mathrm{Mg}, \mathrm{N}, \mathrm{Na}, \mathrm{Pb}$ and $\mathrm{Rb}$ are some of the metals or elements produced from diesel vehicle exhaust. On the other hand, Pey et al. (2009) report that $\mathrm{Al}, \mathrm{Ca}, \mathrm{Mg}, \mathrm{K}$ and $\mathrm{N}$ elements indicate mineral dust sources. Modestou et al. (2014) confirm in a study of local geological samples from across the country of Cyprus that the chemical composition of the local geology constitutes of $\mathrm{SiO}_{2}, \mathrm{Al}_{2} \mathrm{O}_{3}, \mathrm{Fe}_{2} \mathrm{O}_{3}, \mathrm{MgO}, \mathrm{CaO}, \mathrm{CO}_{2}$. Although according to Goudie and Middleton (2001) and Escudero et al. (2011), the $\mathrm{SiO}_{2}$ and $\mathrm{Al}_{2} \mathrm{O}_{3}$ dominate Saharan dust, we cannot conclude with confidence that the $\mathrm{SiO}_{2}, \mathrm{Al}_{2} \mathrm{O}_{3}$ detected in our samples are due to the Saharan events because there were no episodes taking place during the period when the filters were used and finally collected. The indications rather confirm that during this specific sampling period when the filters were used the $\mathrm{SiO}_{2}, \mathrm{Al}_{2} \mathrm{O}_{3}$ detected in our samples are associated with local sources. Elements such as $\mathrm{Na}$ and $\mathrm{Cl}$ in samples indicate sea spry particles (Pey et al., 2009) whereas In (Indium) elements are likely to be related to traffic, especially with break wear processes.Therefore the results of SEM analysis lead to the conclusion that local traffic and geology reflected the majority of airborne particles composition. However, more studies on the chemical composition of airborne particles must be conducted for quantitative insight into the source apportionment of natural and anthropogenic particles.

\subsection{Regional scale effect on $\mathrm{PM}_{10}$ exceedances}

In order to study the regional effect on $\mathrm{PM}_{10}$ concentrations, predictions of the BSC/DREAM model during the dates with exceedances of the $\mathrm{PM}_{10}$ concentration limit values were studied. Model predictions are presented for selected days where: the highest daily average concentration was observed, that was for the two days of $24^{\text {th }}$ January 2009 and $18^{\text {th }}$ May 2009 , as well as for a day where the limit daily mean value of $50 \mu \mathrm{m} / \mathrm{m}^{3}$ was observed $\left(20^{\text {th }} \mathrm{June}\right.$ 2012). In addition, three days between $28^{\text {th }}$ May 2010 until $30^{\text {th }}$ May 2010 are presented in order to show the temporal evolution of the forecasted Sahara dust transportation over the region of Cyprus. The colours on Fig. 12 images illustrate the dust load $\left(\mathrm{g} / \mathrm{m}^{2}\right)$ and the wind vectors at $3000 \mathrm{~m}$ over the Mediterranean sea (3000 m above the sea level is the height where the model calculates the dust load); the exact date and time of the prediction is also referenced in the images. The wind vectors indicate the origin of air masses which carried the particulate matter and therefore we can deduce the region of dust transportation.

Citation details: Mouzourides, P., Kumar, P., Neophytou M.K., 2015. Assessment of long-term measurements of particulate matter and gaseous pollutants in South-East Mediterranean. Atmospheric Environment 107, 148-165. [Online link] 
Fig. 12 presents the temporal evolution of predicted dust load for three consecutive days starting from $28^{\text {th }}$ May 2010 until $30^{\text {th }}$ May 2010, as a representative example of a comparison between $\mathrm{PM}_{10}$ concentration measurements and aerosol load prediction. The average daily value of the measured $\mathrm{PM}_{10}$ concentrations were $67.8 \mu \mathrm{g} / \mathrm{m}^{3}, 55.9 \mu \mathrm{g} / \mathrm{m}^{3}$ and $20.7 \mu \mathrm{g} / \mathrm{m}^{3}$ respectively. On $28^{\text {th }}$ and $29^{\text {th }}$ May 2010 the predicted aerosol load (due to regional transport) is $0.05-0.3 \mathrm{~g} / \mathrm{m}^{2}$ whereas for the $30^{\text {th }}$ May of 2010 it is much lower, $0.0-0.05 \mathrm{~g} / \mathrm{m}^{2}$. This illustrates that exceedances are associated with high background aerosol load (above $0.05 \mathrm{~g} / \mathrm{m}^{2)}$ while concentration measurements within limits are associated with low regional load (below 0.05 $\mathrm{g} / \mathrm{m}^{2)}$. Another confirmation example of this deduction is the example of three days: two with particularly high observed concentrations - or dust events- and another within or just within the limits: the $24^{\text {th }}$ January 2009 with average daily measured value of $332.4 \mu \mathrm{g} / \mathrm{m}^{3}$, the $18^{\text {th }}$ May 2009 with an average daily value of $259.0 \mu \mathrm{g} / \mathrm{m}^{3}$ and the $20^{\text {th }}$ June 2012 where the average daily value was $50.5 \mu \mathrm{g} / \mathrm{m}^{3}$. This observation is consistent with the model predictions for these days:for the first two days, the model shows transport of dust particles from the western Saharan region to Cyprus with a high aerosol load (of $0.75-1.5 \mathrm{~g} / \mathrm{m}^{2}$ ) while on the $20^{\text {th }}$ June 2012 the aerosol load is $0.05-0.3 \mathrm{~g} / \mathrm{m}^{2}$ (see Fig. 13). Furthermore, wind vectors confirm the transport of air masses from Africa from the $\mathrm{W}$ sector. The above results are a strong indication of the effect of regional transport of dust on $\mathrm{PM}_{10}$ exceedances, a result that is also found for other locations, such as London by Charron et al. (2007) using backward trajectories methods.

\section{Summary and conclusions}

Long-term measurement data of particulate matter, gaseous pollutants and meteorological conditions were collected in the period from $1^{\text {st }}$ April 2008 to $31^{\text {st }}$ December 2013 in the city of Nicosia (Cyprus) representing a South-East European region. The data was analysed with the aim to identify multi-scale and multi-kind determining influences on pollutant concentrations as well as to identify the trends of pollutant concentrations. The mean hourly-average value of NOx and CO recorded over the entire period were $13.6 \pm 21.5 \mathrm{ppb}$ and $1.5 \pm 1.1 \mathrm{ppm}$ respectively, whilst the mean hourly-average value of $\mathrm{PM}_{10}$ concentration was $32.4 \pm 45.6 \mu \mathrm{g} / \mathrm{m}^{3}$. The meteorological conditions in the region were characterised by $\mathrm{W}$ and $\mathrm{W}-\mathrm{NW}$ prevailing wind directions, while the dominant wind speed values ranged from 0.5 to $1 \mathrm{~m} / \mathrm{s}$. The most frequently measured hourly values of AT in Nicosia were in the range of 10 to $30{ }^{\circ} \mathrm{C}$; $\mathrm{RH}$ was observed to range between $75 \%$ and $90 \%$ while RF was found to be poor since its values were never greater than 0.0025 $\mathrm{mm} / \mathrm{h}$. 
The conclusions of the study are summarized as follows:

1. More detailed analysis of the meteorological and concentration data using Principal Component Analysis (PCA) yields 4 Principal Components (PCs) that explain about 65\% of the total variance. The analysis showed that the most significant PC is meteorology which is strongly correlated with AT, RH, SR, WS and BP parameters. A second PC, composed by $\mathrm{CO}, \mathrm{PM}_{10}$ and $\mathrm{WD}$, indicates the effect of automobiles traffic under the influence of WD. Furthermore, it is found that $\mathrm{CO}, \mathrm{NO}_{2}, \mathrm{PM}_{10}$ concentrations are primarily due to local road traffic, and less due to geological minerals and sea spry sources, but $\mathrm{PM}_{10}$ exceedances or high $\mathrm{PM}_{10}$ concentration values were associated with high regional background concentrations. The dataset analysis also reveals seasonal effects on $\mathrm{CO}, \mathrm{NOx}$ and $\mathrm{PM}_{10}$ concentrations: high concentrations of $\mathrm{CO}$ and NOx were observed during winter, whilst high $\mathrm{PM}_{10}$ concentrations were observed during spring and autumn.

2. There was not any significant change in the trends (either downward or upward) of pollutant concentrations in Nicosia identified, although some abrupt changes in $\mathrm{CO}$ concentrations were identified due to the seasonal cycle (e.g. in November 2009). The analysis rather points that the improved traffic emission policies are not reflected as reduction of pollutants concentrations.

3. SEM results indicate that local traffic, geological minerals and sea spray sources are responsible for the majority of airborne particles found on the elemental composition of the analysed filters. Although the characteristic constituents of Saharan dust $\mathrm{SiO}_{2}$ and $\mathrm{Al}_{2} \mathrm{O}_{3}$ were also detected in our sample filters, we cannot attribute their origin solely to Sahara, because these are also found in the local Cypriot geological formations. To distinguish and attribute such differences, more filters spanning different periods - some containing Saharan episodes and some not, need to be further collected and analyzed for more definite conclusions.

4. However, numerical simulations using the Dust REgional Atmospheric Model give a strong indication that the high $\mathrm{PM}_{10}$ concentrations and the $\mathrm{PM}_{10}$ exceedances are strongly associated with high regional background dust concentrations transported during westerly winds - related to Saharan episodes.

Citation details: Mouzourides, P., Kumar, P., Neophytou M.K., 2015. Assessment of long-term measurements of particulate matter and gaseous pollutants in South-East Mediterranean. Atmospheric Environment 107, 148-165. [Online link] 
This study contributes a valuable dataset to literature and analysis on the long-term trends of both particulate matter and gaseous pollutants in Cyprus which represents a typical Mediterranean environment. The findings can also be useful to neighbouring countries and locations with similar meteorological conditions. The influence of multi-scale meteorology and multi-kind contributions on pollutant concentrations was crucial in the focus of this study and it is intended to provide useful insights in the future development of appropriate regulatory tools for the design of mitigation strategies. Furthermore, the data can allow performance evaluation of air quality models under variable environmental conditions. While a number of unique features of long-term trends of pollutants are revealed, further research is recommended to apportion the quantitative contribution of various sources towards the studied pollutants.

\section{Acknowledgements}

This work was funded by the Cyprus National Research Promotion Foundation and European

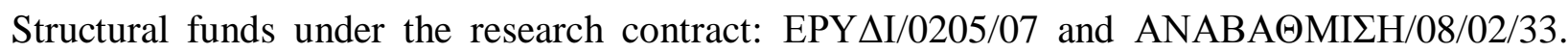
Petros Mouzourides and Dr Prashant Kumar wish to thank the Erasmus Exchange Program for funding exchange visits at the University of Surrey, UK, and the University of Cyprus, respectively, in order to help develop this work. The authors also thank Prof John Watts, Mr. Chris Burt and Mr. Sujit Gurung of MicroStructural Studies Unit (MSSU) of the University of Surrey for their help and granting access to their facilities for SEM experiments as well as Dr Andreas Kyprianou of the University of Cyprus for useful discussions. Dr. Marina Neophytou wishes also to acknowledge the late Mr. Georgios Orthodoxou for around-the-clock technical support of the Air Quality Monitoring Station and this work is warmly dedicated to him as an expression of this appreciation.

\section{References}

Abdul-Wahab, S.A., Bakheit, C.S., Al-Alawi, S.M., 2005. Principal component and multiple regression analysis in modelling of ground-level ozone and factors affecting its concentrations. Environmental Modelling \& Software 20, 1263-1271.

Bobbink, R., Hornung, M., Roelofs, J.G., 1998. The effects of air-borne nitrogen pollutants on species diversity in natural and semi-natural European vegetation. Journal of Ecology, 86, 717-738. 
Carslaw, D.C., Ropkins, K., Bell, M.C., 2006. Change-point detection of gaseous and particulate traffic-related pollutants at a roadside location. Environmental science \& technology, 40(22), 6912-6918.

Carslaw, D.C., Ropkins, K., 2012. Openair - An R package for air quality data analysis. Environmental Modelling \& Software 27, 52-61.

Carslaw, D.C., Beevers, S.D., 2013. Characterising and understanding emission sources using bivariate polar plots and k-means clustering. Environmental Modelling \& Software 40, 325-329.

Charron, A., Harrison, R.M., Quincey, P., 2007. What are the sources and conditions responsible for exceedences of the $24 \mathrm{~h} \mathrm{PM}_{10}$ limit value $\left(50 \mu \mathrm{gm}^{-3}\right)$ at a heavily trafficked London site? Atmospheric Environment 41, 1960-1975.

Derwent, R.G., Simmonds, P. G., Seuring, S., Dimmer, C., 1998. Observation and interpretation of the seasonal cycles in the surface concentrations of ozone and carbon monoxide at Mace Head, Ireland from 1990 to 1994. Atmospheric Environment, 32, 145-157.

EU Directive, Directive 2008/50/EC of the European Parliament and of the Council of 21 May 2008 on ambient air quality and cleaner air for Europe, http://eurlex.europa.eu/LexUriServ/LexUriServ.do?uri=CELEX:32008L0050:EN:NOT, 2008.

Escudero, M., Stein, A., Draxler, R., Querol, X., Alastuey, A., Castillo, S., Avila, A., 2011. Source apportionment for African dust outbreaks over the Western Mediterranean using the HYSPLIT model. Atmospheric Research, 99, 518-527.

Gerassopoulos, E., Kouvarakis, G., Babasakalis, P., Vrekoussis, M., Putaud, J. P., Mihalopoulos, N., 2006. Origin and variability of particulate matter $\left(\mathrm{PM}_{10}\right)$ mass concentrations over the Eastern Mediterranean. Atmospheric Environment, 40, 4679-4690.

Goudie, A.S., Middleton, N.J., 2001. Saharan dust storms: nature and consequences. EarthScience Reviews, 56, 179-204.

Harrison, R.M., 2004. Key pollutants - airborne particles. Science of the Total Environment 334, 3-8.

Harrison, R.M., Stedman, J., Derwent, D., 2008. New Directions: Why are $\mathrm{PM}_{10}$ concentrations in Europe not falling? Atmospheric Environment 42, 603-606.

Heal, M.R., Kumar, P., Harrison, R.M., 2012. Particles, air quality, policy and health. Chemical Society Reviews 41, 6606-6630.

Citation details: Mouzourides, P., Kumar, P., Neophytou M.K., 2015. Assessment of long-term measurements of particulate matter and gaseous pollutants in South-East Mediterranean. Atmospheric Environment 107, 148-165. [Online link] 
Huang, W., Tan, J., Kan, H., Zhao, N., Song, W., Song, G., Chenf G., Jiange L., Jiange C., Chenc R., Chen, B. (2009). Visibility, air quality and daily mortality in Shanghai, China. Science of the total environment, 407, 3295-3300.

Jolliffe, I. T., 2002. Principal Component Analysis, Second edition. Springer Series in Statistics. Kanakidou, M., Mihalopoulos, N., Kindap, T., Im, U., Vrekoussis, M., Gerasopoulos, E., Dermitzaki, E., Unal A., Koçak, M., Markakis, K., et al., 2011. Megacities as hot spots of air pollution in the East Mediterranean. Atmospheric Environment, 45, 1223-1235.

Koulouri, E., Saarikoski, S., Theodosi, C., Markaki, Z., Gerasopoulos, E., Kouvarakis, G., Mäkelä, T., Hillamo, R., Mihalopoulos, N., 2008. Chemical composition and sources of fine and coarse aerosol particles in the Eastern Mediterranean. Atmospheric Environment, $42,6542-6550$.

Krzanowski, W.J., 2000. Principles of multivariate analysis. Clarendon.

Kumar, P., Fennell, P., Britter, R., 2008. Effect of wind direction and speed on the dispersion of nucleation and accumulation mode particles in an urban street canyon. Science of the Total Environment 402, 82-94.

Kumar, P., Imam, B., 2013. Footprints of air pollution and changing environment on the sustainability of built infrastructure. Science of the Total Environment 444, 85-101.

Kumar, P., Morawska, M., 2014. Recycling concrete: An undiscovered source of ultrafine particles. Atmospheric Environment, 90, 51-58.

Kumar, P., Morawska, L., Birmili, W., Paasonen, P., Hu, M., Kulmala, M., Harrison, R.M., Norford, L., Britter, R., 2014b. Ultrafine particles in cities. Environment international 66, $1-10$.

Matlab $^{\odot}$, R2012b, URL http://www.mathworks.com.

Matti Maricq, M., 2007. Chemical characterization of particulate emissions from diesel engines: a review. Journal of Aerosol Science, 38, 1079-1118.

Michaelides, S., Evripidou, P., Kallos, G., 1999. Monitoring and predicting Saharan Desert dust events in the eastern Mediterranean. Weather, 54, 359-365.

Middleton, N., Yiallouros, P., Kleanthous, S., Kolokotroni, O., Schwartz, J., Dockery, D.W., Demokritou P., Koutrakis, P., 2008. A 10-year time-series analysis of respiratory and cardiovascular morbidity in Nicosia, Cyprus: the effect of short-term changes in air pollution and dust storms. Environ Health, 7, 10-1186.

Citation details: Mouzourides, P., Kumar, P., Neophytou M.K., 2015. Assessment of long-term measurements of particulate matter and gaseous pollutants in South-East Mediterranean. Atmospheric Environment 107, 148-165. [Online link] 
Modestou, S., Theodoridou, M., Fournari, R., Ioannou, I., 2014. Physico-mechanical properties and durability performance of natural building and decorative carbonate stones from Cyprus. Geological Society, London, Special Publications (accepted)

Moreno, T., Gibbons, W., Jones, T., Richards, R., 2003. The geology of ambient aerosols: characterising urban and rural/coastal silicate $\mathrm{PM}_{10-} 2.5$ and $\mathrm{PM}_{2.5}$ using high-volume cascade collection and scanning electron microscopy. Atmospheric Environment, 37, 4265-4276

Montgomery, D. C., 2007. Introduction to statistical quality control. John Wiley \& Sons.

Neophytou MK-A, Goussis D, Van Loon M, Mastorakos E, 2004. Reduced chemical mechanisms for atmospheric pollution using computational singular perturbation analysis. Atmos Environ 38(22):3661-3673

Neophytou, M., Goussis, D., Mastorakos, E., Britter, R., 2005. “The conceptual development of a simple scale-adaptive reactive pollutant dispersion model”. Atmospheric Environment 39 (15), 2787-2794.

Neophytou, M., Gowardhan, A., Brown, M., 2011. An inter-comparison of three urban wind models using Oklahoma City Joint Urban 2003 wind field measurements. Journal of Wind Engineering and Industrial Aerodynamics, 99, 357-368.

Neophytou, M.K.-A., Markides, C.N., Fokaides, P.A., 2014. An experimental study of the flow through and over two-dimensional rectangular roughness elements: Deductions for urban boundary layer parameterizations and exchange processes. Physics of Fluids, Vol. 26, No.8, http://dx.doi.org/10.1063/1.4892979]

Nickovic, S., Kallos, G., Papadopoulos, A., Kakaliagou, O., 2001. A model for prediction of desert dust cycle in the atmosphere. Journal of Geophysical Research: Atmospheres (19842012) $106,18113-18129$.

Panagiotou, I., Neophytou, M.K.A., Hamlyn, D., Britter, R.E., 2013. City breathability as quantified by the exchange velocity and its spatial variation in real inhomogeneous urban geometries: An example from central London urban area. Science of The Total Environment, 442, 466-477.

Pasquill, F., 1961. The estimation of the dispersion of windborne material. Meteorol. Mag 90, $33-49$.

Pey, J., Querol, X., Alastuey, A., Rodríguez, S., Putaud, J.P., Van Dingenen, R., 2009. Source apportionment of urban fine and ultra-fine particle number concentration in a Western Mediterranean city. Atmospheric Environment 43, 4407-4415.

Citation details: Mouzourides, P., Kumar, P., Neophytou M.K., 2015. Assessment of long-term measurements of particulate matter and gaseous pollutants in South-East Mediterranean. Atmospheric Environment 107, 148-165. [Online link] 
Pope III, C.A., Dockery, D.W., 2006. Health effects of fine particulate air pollution: lines that connect. Journal of the Air \& Waste Management Association, 56, 709-742.

R Development Core Team, 2011. R: A language and environment for statistical computing. R Foundation for Statistical Computing, Vienna, Austria. ISBN 3-900051-07-0, URL http://www.R-project.org/.

Saffari, A., Daher, N., Samara, C., Voutsa, D., Kouras, A., Manoli, E., Karagkiozidou, O., Vlachokostas, C., Moussiopoulos, N., Shafer, M.M., 2013. Increased Biomass Burning Due to the Economic Crisis in Greece and Its Adverse Impact on Wintertime Air Quality in Thessaloniki. Environmental science \& technology 47, 13313-13320.

Seinfeld, J.H., Pandis, S.N., 2012. Atmospheric chemistry and physics: from air pollution to climate change. John Wiley \& Sons.

Statheropoulos, M., Vassiliadis, N., Pappa, A., 1998. Principal component and canonical correlation analysis for examining air pollution and meteorological data. Atmospheric Environment 32, 1087-1095.

Tiwary, A., Kumar, P., 2014. Impact evaluation of green-grey infrastructure interaction on builtspace integrity: an emerging perspective to urban ecosystem service. Science of the Total Environment 487, 350-360.

Viana, M., Pey, J., Querol, X., Alastuey, A., de Leeuw, F., Lükewille, A., 2013. Natural sources of atmospheric aerosols influencing air quality across Europe. Science of the Total Environment 472, 825-833.

Citation details: Mouzourides, P., Kumar, P., Neophytou M.K., 2015. Assessment of long-term measurements of particulate matter and gaseous pollutants in South-East Mediterranean. Atmospheric Environment 107, 148-165. [Online link] 
Table 1: Statistical analysis of atmospheric and air quality parameters during the period of $1^{\text {st }}$ April 2008 to $31^{\text {st }}$ December 2013. The words “Aver" and "SD" stand for the average value and standard deviation, respectively.

\begin{tabular}{|c|c|c|c|c|c|c|}
\hline \multirow{2}{*}{ Parameters } & \multicolumn{6}{|c|}{ Year } \\
\hline & 2008 & 2009 & 2010 & 2011 & 2012 & 2013 \\
\hline BP (mbar) & 1001.00 & 999.93 & 998.16 & 1002.68 & 1002.10 & 1055.11 \\
\hline Aver (SD) & $(12.72)$ & $(5.24)$ & $(5.13)$ & $(5.64)$ & $(6.06)$ & $(47.81)$ \\
\hline RH (\%) & 61.71 & 64.47 & 63.73 & 65.33 & 66.02 & 59.33 \\
\hline Aver (SD) & $(20.13)$ & $(19.85)$ & (19.69) & $(18.16)$ & $(18.94)$ & (20.08) \\
\hline $\begin{array}{c}\text { RF (mm) } \\
\text { Aver (SD) }\end{array}$ & $\begin{array}{c}2 \times 10^{-6} \\
\left(1 \times 10^{-4)}\right.\end{array}$ & $\begin{array}{c}3 \times 10^{-7} \\
\left(3 \times 10^{-5}\right)\end{array}$ & $\begin{array}{c}0 \times 10^{-0} \\
\left(0 \times 10^{-0}\right)\end{array}$ & $\begin{array}{c}9 \times 10^{-5} \\
\left(4 \times 10^{-3}\right)\end{array}$ & $\begin{array}{c}1 \times 10^{-4} \\
\left(5 \times 10^{-3}\right)\end{array}$ & $\begin{array}{c}0 \times 10^{-0} \\
\left(0 \times 10^{-0}\right)\end{array}$ \\
\hline $\begin{array}{c}\text { AT }\left({ }^{\mathbf{O}} \mathbf{C}\right) \\
\operatorname{Aver}(\mathbf{S D})\end{array}$ & $\begin{array}{l}21.62 \\
(7.48)\end{array}$ & $\begin{array}{l}18.95 \\
(8.13)\end{array}$ & $\begin{array}{l}20.78 \\
(8.55)\end{array}$ & $\begin{array}{l}19.60 \\
(8.37)\end{array}$ & $\begin{array}{l}18.51 \\
(8.56)\end{array}$ & $\begin{array}{l}20.97 \\
(8.91)\end{array}$ \\
\hline $\begin{array}{c}\mathrm{SR}\left(\mathrm{W} / \mathbf{m}^{2}\right) \\
\text { Aver }(\mathrm{SD})\end{array}$ & $\begin{array}{c}226.49 \\
(303.70)\end{array}$ & $\begin{array}{c}202.75 \\
(287.56)\end{array}$ & $\begin{array}{c}211.28 \\
(294.97)\end{array}$ & $\begin{array}{c}207.96 \\
(291.71)\end{array}$ & $\begin{array}{c}205.03 \\
(291.50)\end{array}$ & $\begin{array}{c}73.57 \\
(151.05)\end{array}$ \\
\hline $\begin{array}{c}\text { WS (m/s) } \\
\text { Aver (SD) }\end{array}$ & $\begin{array}{c}1.68 \\
(1.21)\end{array}$ & $\begin{array}{c}1.64 \\
(1.19)\end{array}$ & $\begin{array}{c}1.61 \\
(1.21)\end{array}$ & $\begin{array}{c}2.15 \\
(1.57)\end{array}$ & $\begin{array}{c}2.23 \\
(1.55)\end{array}$ & $\begin{array}{c}2.47 \\
(1.53)\end{array}$ \\
\hline $\begin{array}{l}\text { WD (deg) } \\
\text { Aver (SD) }\end{array}$ & $\begin{array}{l}225.89 \\
(88.92)\end{array}$ & $\begin{array}{l}223.86 \\
(88.09)\end{array}$ & $\begin{array}{l}217.77 \\
(86.36)\end{array}$ & $\begin{array}{c}191.08 \\
(102.38)\end{array}$ & $\begin{array}{c}189.58 \\
(110.49)\end{array}$ & $\begin{array}{c}200.80 \\
(110.53)\end{array}$ \\
\hline $\begin{array}{l}\text { NOx (ppb) } \\
\text { Aver (SD) }\end{array}$ & $\begin{array}{c}15.53 \\
(35.68)\end{array}$ & $\begin{array}{c}8.50 \\
(13.30)\end{array}$ & $\begin{array}{c}17.99 \\
(21.04)\end{array}$ & $\begin{array}{c}13.94 \\
(19.83)\end{array}$ & $\begin{array}{c}11.07 \\
(13.89)\end{array}$ & $\begin{array}{c}15.89 \\
(18.02)\end{array}$ \\
\hline $\begin{array}{l}\text { CO (ppm) } \\
\text { Aver (SD) }\end{array}$ & $\begin{array}{c}0.53 \\
(0.42)\end{array}$ & $\begin{array}{c}2.39 \\
(0.86)\end{array}$ & $\begin{array}{c}2.01 \\
(0.59)\end{array}$ & $\begin{array}{l}1.05 \\
(1.43)\end{array}$ & $\begin{array}{l}1.33 \\
(0.48)\end{array}$ & $\begin{array}{c}0.45 \\
(0.38)\end{array}$ \\
\hline $\begin{array}{c}\mathbf{P M}_{10} \\
\left(\mu \mathrm{g} / \mathbf{m}^{3}\right) \\
\operatorname{Aver}(\mathbf{S D})\end{array}$ & $\begin{array}{c}67.44 \\
(70.55)\end{array}$ & $\begin{array}{c}31.45 \\
(50.84)\end{array}$ & $\begin{array}{c}11.48 \\
(22.80)\end{array}$ & $\begin{array}{c}27.29 \\
(31.84)\end{array}$ & $\begin{array}{c}30.15 \\
(29.61)\end{array}$ & $\begin{array}{l}28.61 \\
(20.48)\end{array}$ \\
\hline
\end{tabular}

Citation details: Mouzourides, P., Kumar, P., Neophytou M.K., 2015. Assessment of long-term measurements of particulate matter and gaseous pollutants in South-East Mediterranean. Atmospheric Environment 107, 148-165. [Online link] 
Table 2: The PCA results for the meteorological variables and criteria pollutants.

\begin{tabular}{|c|c|c|c|c|c|c|c|c|}
\hline \multicolumn{6}{|c|}{ Principal Component } & \multicolumn{3}{|c|}{ Initial Eigenvalues } \\
\hline $\begin{array}{l}\text { Variabl } \\
\mathrm{e}\end{array}$ & 1 & 2 & 3 & 4 & $\begin{array}{c}\text { Principal } \\
\text { Componen } \\
\mathrm{t}\end{array}$ & Total & $\begin{array}{c}\% \text { of } \\
\text { Varianc } \\
\mathrm{e}\end{array}$ & $\begin{array}{c}\text { Cumulativ } \\
\text { e } \%\end{array}$ \\
\hline NOx & -0.37 & 0.19 & -0.22 & 0.76 & 1 & 2.72 & 27.25 & 27.25 \\
\hline $\mathrm{CO}$ & -0.06 & -0.64 & -0.51 & 0.29 & 2 & 1.45 & 14.54 & 41.79 \\
\hline $\mathrm{PM}_{10}$ & 0.03 & 0.64 & 0.29 & 0.37 & 3 & 1.28 & 12.76 & 54.55 \\
\hline WS & 0.50 & -0.14 & 0.63 & 0.00 & 4 & 1.05 & 10.50 & 65.05 \\
\hline WD & 0.11 & -0.50 & 0.56 & 0.47 & 5 & 1.00 & 9.99 & 75.04 \\
\hline $\mathrm{BP}$ & -0.53 & 0.44 & 0.06 & -0.04 & 6 & 0.88 & 8.81 & 83.85 \\
\hline RH & -0.84 & -0.18 & 0.15 & -0.15 & 7 & 0.59 & 5.90 & 89.75 \\
\hline RF & 0.02 & 0.03 & 0.06 & -0.07 & 8 & 0.53 & 5.27 & 95.03 \\
\hline $\mathrm{AT}$ & 0.89 & -0.02 & -0.10 & 0.03 & 9 & 0.29 & 2.93 & 97.95 \\
\hline SR & 0.73 & 0.32 & -0.34 & 0.08 & 10 & 0.20 & 2.05 & 100.00 \\
\hline
\end{tabular}

Note: WS =Wind speed ; WD = Wind direction; BP = Barometric pressure; RH = Relative humidity; RF $=$ Rainfall; $\mathrm{AT}=$ Ambient temperature; $\mathrm{SR}=$ Solar radiation; in bold $=$ numbers whose absolute value is above 0.5 hence indicating significance. 
Table 3: Summary of the most significant factors affecting the pollutant concentrations in Nicosia area.

\begin{tabular}{|c|c|c|c|c|c|c|c|c|}
\hline Factor & Winter & Spring & $\begin{array}{l}\text { Summe } \\
\mathbf{r}\end{array}$ & $\begin{array}{l}\text { Autum } \\
\text { n }\end{array}$ & $\begin{array}{l}\text { Winte } \\
\mathbf{r}\end{array}$ & $\begin{array}{l}\text { Sprin } \\
\text { g }\end{array}$ & $\begin{array}{l}\text { Summe } \\
\mathbf{r}\end{array}$ & $\begin{array}{l}\text { Autum } \\
\text { n }\end{array}$ \\
\hline $\begin{array}{l}\text { Atmospheri } \\
\text { c stability }\end{array}$ & $\begin{array}{c}\text { Unstabl } \\
\mathrm{e}\end{array}$ & $\begin{array}{c}\text { Very } \\
\text { Unstabl } \\
\text { e }\end{array}$ & $\begin{array}{c}\text { Unstabl } \\
\mathrm{e}\end{array}$ & $\begin{array}{c}\text { Very } \\
\text { Unstabl } \\
\text { e }\end{array}$ & + & + & + & + \\
\hline Traffic & $\mathrm{h}$ & $\mathrm{h}$ & 1 & $\mathrm{~m}$ & + & + & 0 & + \\
\hline Vegetation & $\mathrm{n}$ & $\mathrm{h}$ & $\mathrm{m}$ & 1 & 0 & - & - & 0 \\
\hline $\begin{array}{c}\text { Temperatur } \\
\text { e }\end{array}$ & 10.65 & 18.08 & 28.20 & 21.20 & - & - & - & 0 \\
\hline Wind speed & 1.54 & 2.00 & 2.35 & 1.85 & $\mathrm{~h}$ & $\mathrm{~h}$ & $\mathrm{~h}$ & $\mathrm{~h}$ \\
\hline $\begin{array}{c}\text { Solar } \\
\text { Radiation }\end{array}$ & 264.10 & 433.40 & 511.97 & 350.46 & $\mathrm{~m}$ & $\mathrm{~m}$ & $\mathrm{~m}$ & $\mathrm{~m}$ \\
\hline Sigma Theta & 39.55 & 37.78 & 36.73 & 37.24 & & & & \\
\hline $\begin{array}{c}\text { Precipitatio } \\
\text { n }\end{array}$ & $1.3060^{-}$ & $1.4210^{-}$ & $1.38{ }_{5} 10^{-}$ & $1.1960^{-}$ & $\mathrm{n}$ & $\mathrm{n}$ & $\mathrm{n}$ & 0 \\
\hline
\end{tabular}

Note: Acronyms "h", "m" "l" and "n" stands for high, medium, low and no influence, respectively. Symbols,+- and 0 denote gain, loss and no effect on pollutant concentrations. 
Table 4: Long-term seasonal average values for criteria pollutants NOx. CO and $\mathrm{PM}_{10}$ and also WS and AT. All data representing a time span of $1^{\text {st }}$ April 2008 to $31^{\text {st }}$ December 2013. The words "Aver" and "SD" stand for average value and standard deviation, respectively.

\begin{tabular}{|c|c|c|c|c|c|}
\hline & $\begin{array}{l}\text { NOx (ppb) } \\
\text { Aver (SD) } \\
\end{array}$ & $\begin{array}{l}\text { CO (ppm) } \\
\text { Aver (SD) }\end{array}$ & $\begin{array}{c}\mathrm{PM}_{10}\left(\mu \mathrm{g} / \mathrm{m}^{3}\right) \\
\text { Aver }(\mathrm{SD})\end{array}$ & $\begin{array}{c}\text { WS (m/s) } \\
\text { Aver (SD) } \\
\end{array}$ & $\begin{array}{c}\text { AT }\left(^{(0}\right) \\
\text { Aver (SD) }\end{array}$ \\
\hline Winter & $\begin{array}{c}19.95 \\
(23.36)\end{array}$ & $1.91(1.18)$ & $\begin{array}{c}25.32 \\
(42.44)\end{array}$ & $1.54(1.34)$ & $10.65(4.08)$ \\
\hline Spring & $\begin{array}{c}10.47 \\
(13.34)\end{array}$ & $1.51(0.89)$ & $\begin{array}{c}36.88 \\
(41.81)\end{array}$ & $2.00(1.47)$ & $18.08(7.07)$ \\
\hline Summer & 8.09 (26.93) & $1.48(1.10)$ & $\begin{array}{c}29.36 \\
(42.87)\end{array}$ & 2.35 (1.49) & $28.20(5.27)$ \\
\hline Autumn & $\begin{array}{c}13.25 \\
(16.06)\end{array}$ & $1.39(1.24)$ & $\begin{array}{c}34.08 \\
(43.34)\end{array}$ & $1.85(1.29)$ & $21.20(6.49)$ \\
\hline
\end{tabular}

Note: $\mathrm{WS}=$ Wind speed ; AT $=$ Ambient temperature.

Citation details: Mouzourides, P., Kumar, P., Neophytou M.K., 2015. Assessment of long-term measurements of particulate matter and gaseous pollutants in South-East Mediterranean. Atmospheric Environment 107, 148-165. [Online link] 
Table 5: Number of exceedences of 24-hour mean values of $\mathrm{PM}_{10}$ concentrations per season for each year separately.

\begin{tabular}{lccccccc}
\hline & $\mathbf{2 0 0 8}$ & $\mathbf{2 0 0 9}$ & $\mathbf{2 0 1 0}$ & $\mathbf{2 0 1 1}$ & $\mathbf{2 0 1 2}$ & $\mathbf{2 0 1 3}$ & Total \\
\hline Spring & 25 & 20 & 5 & 18 & 13 & 1 & 82 \\
\hline Summer & 85 & 2 & 0 & 3 & 9 & 3 & 102 \\
\hline Autumn & 61 & 10 & 0 & 13 & 0 & 10 & 94 \\
\hline Winter & 0 & 32 & 9 & 0 & 2 & 0 & 43 \\
\hline Total Days & 171 & 64 & 14 & 34 & 24 & 14 & 321 \\
\hline
\end{tabular}

Citation details: Mouzourides, P., Kumar, P., Neophytou M.K., 2015. Assessment of long-term measurements of particulate matter and gaseous pollutants in South-East Mediterranean. Atmospheric Environment 107, 148-165. [Online link] 
Table 6: Anthropogenic and natural processes exist in the surrounding area, and the level of their influence on $\mathrm{PM}_{10}$ concentration in region. Symbols,,,+++--- and 0 denote great gain, gain, great loss, loss and no effect of the corresponding processes on $\mathrm{PM}_{10}$ concentrations, respectively.

\begin{tabular}{clc}
\hline & \multicolumn{1}{c}{$\begin{array}{c}\text { Processes in the } \\
\text { surrounding area }\end{array}$} & $\begin{array}{c}\text { Effect on PM } \\
\text { concentrations }\end{array}$ \\
\hline & $\begin{array}{l}\text { Exhaust emissions } \\
\text { Emissions from abrasion } \\
\text { processes (i.e tire-wear. }\end{array}$ & ++ \\
$\begin{array}{c}\text { Anthropogenic } \\
\text { processes }\end{array}$ & $\begin{array}{l}\text { brake lining) } \\
\text { Road dust resuspension }\end{array}$ & 0 \\
& Building works & + \\
& Agriculture processes & + \\
Natural & Wind dust resuspension & ++ \\
\hline processes & Regional background & ++ \\
& sources & ++ \\
& Sea salt & + \\
& Dry deposition & -- \\
& Wet deposition & - \\
\hline
\end{tabular}

Citation details: Mouzourides, P., Kumar, P., Neophytou M.K., 2015. Assessment of long-term measurements of particulate matter and gaseous pollutants in South-East Mediterranean. Atmospheric Environment 107, 148-165. [Online link] 
Table 7: Elemental composition of PTFE filters. Elements listed in alphabetical order.

\begin{tabular}{ll}
\hline Clean Filter & Used Filters \\
\hline $\mathrm{Au}$ (Gold) & $\mathrm{Al}$ (Aluminium) \\
$\mathrm{C}$ (Carbon) & $\mathrm{Ca}$ (Calcium) \\
$\mathrm{F}$ (Fluorine) & $\mathrm{Cl}$ (Chlorine) \\
$\mathrm{Fe}$ (Iron) & $\mathrm{In}$ (Indium) \\
& $\mathrm{K}$ (Potassium) \\
& $\mathrm{Mg}$ (Magnesium) \\
& $\mathrm{N}$ (Nitrogen) \\
& $\mathrm{Na}$ (Sodium) \\
& $\mathrm{O}$ (Oxygen) \\
& $\mathrm{Pb}$ (Lead) \\
& $\mathrm{Rb}$ (Rubitium) \\
\hline
\end{tabular}

Citation details: Mouzourides, P., Kumar, P., Neophytou M.K., 2015. Assessment of long-term measurements of particulate matter and gaseous pollutants in South-East Mediterranean. Atmospheric Environment 107, 148-165. [Online link] 


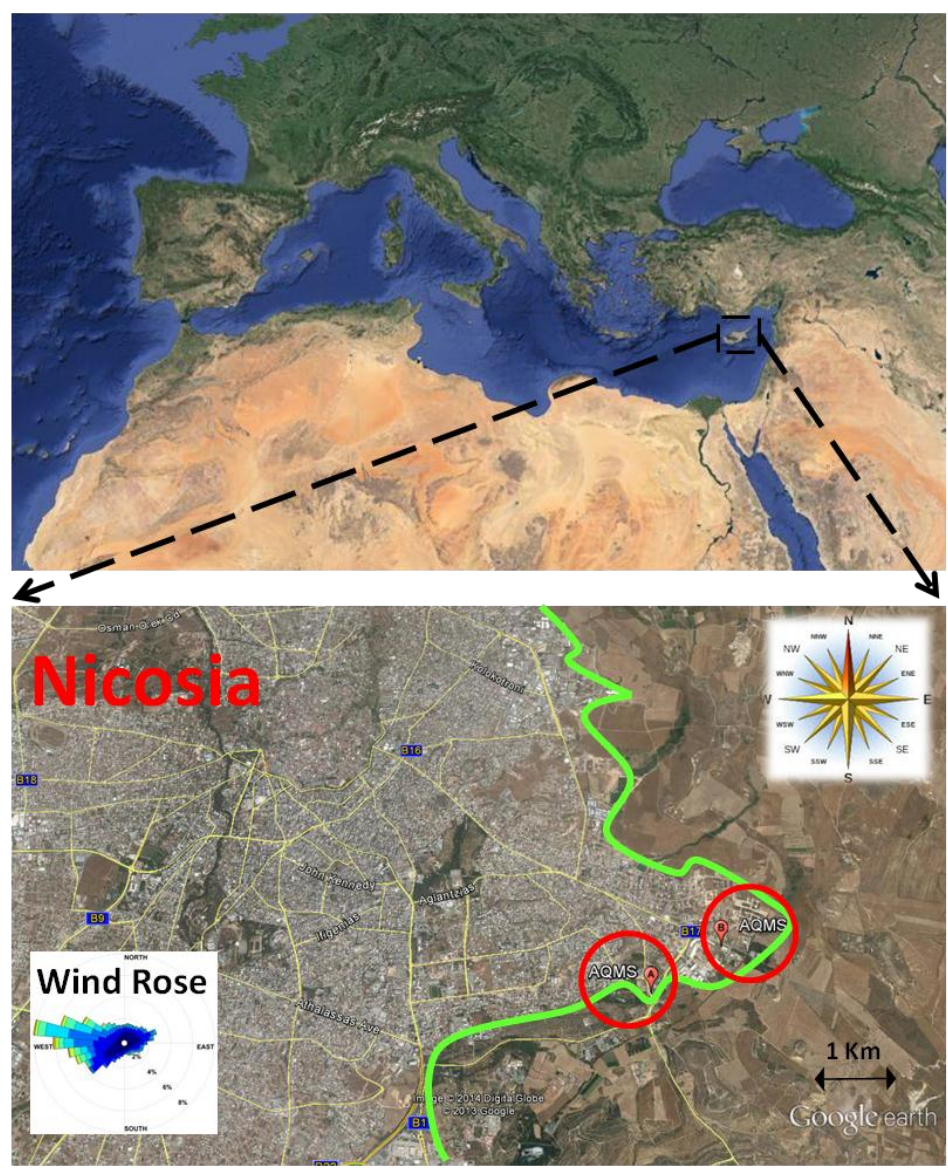

Fig. 1: Google Earth image depicting the two different locations of the University of Cyprus AQMS in Nicosia, Cyprus. Positions A and B are the initial and new locations of the station, respectively. Wind rose shows the wind directions in the area based on daily averaged values.

Citation details: Mouzourides, P., Kumar, P., Neophytou M.K., 2015. Assessment of long-term measurements of particulate matter and gaseous pollutants in South-East Mediterranean. Atmospheric Environment 107, 148-165. [Online link] 
(a)

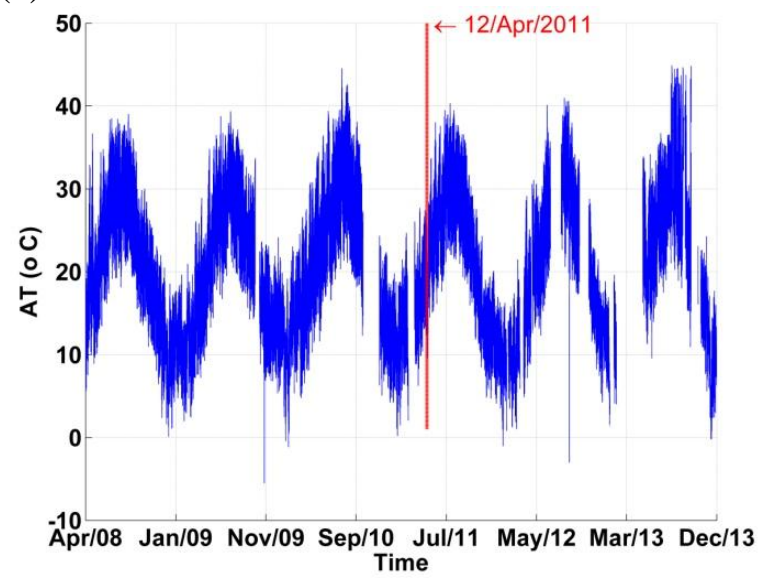

(c)

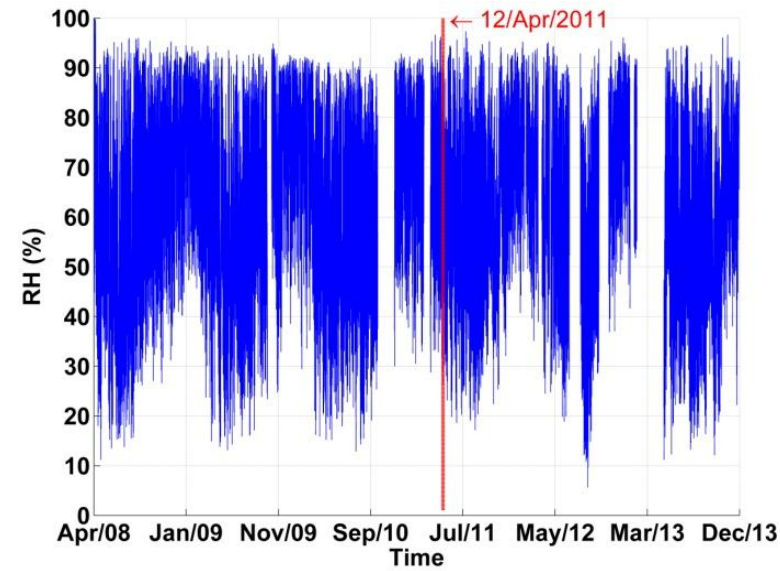

(e)

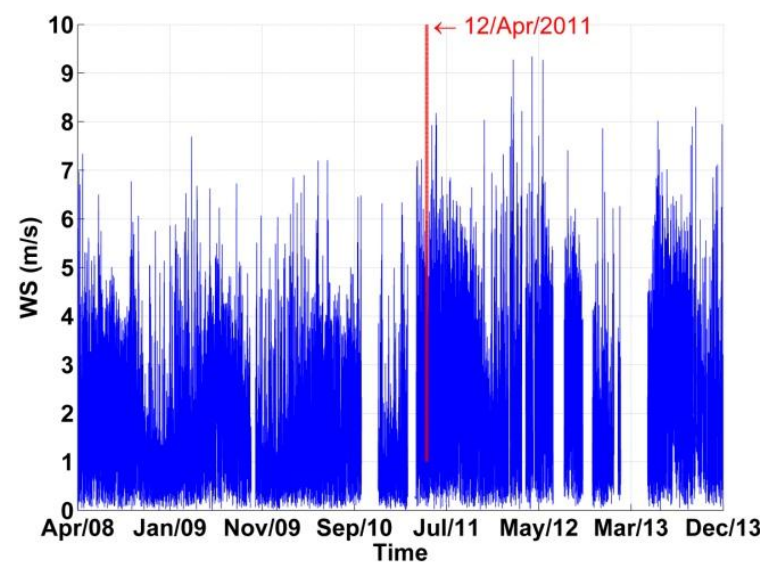

$(\mathrm{g})$ (b)

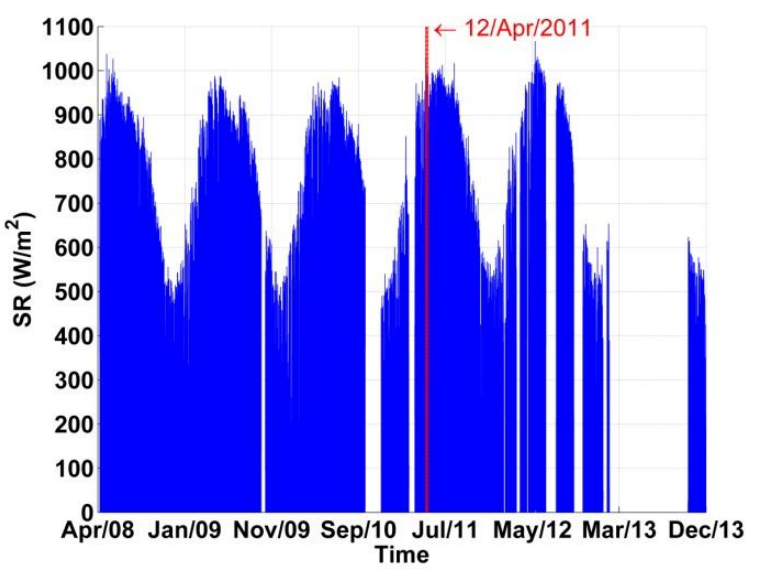

(d)

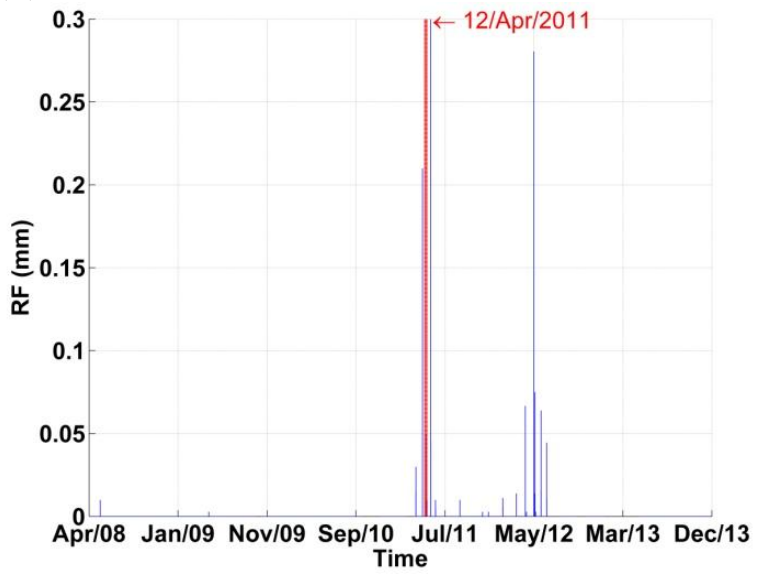

(f)

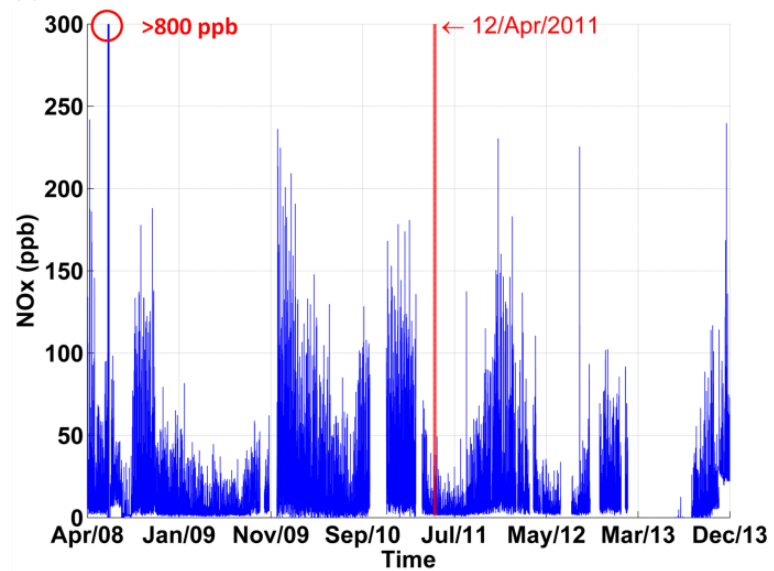

(h)

Citation details: Mouzourides, P., Kumar, P., Neophytou M.K., 2015. Assessment of long-term measurements of particulate matter and gaseous pollutants in South-East Mediterranean. Atmospheric Environment 107, 148-165. [Online link] 

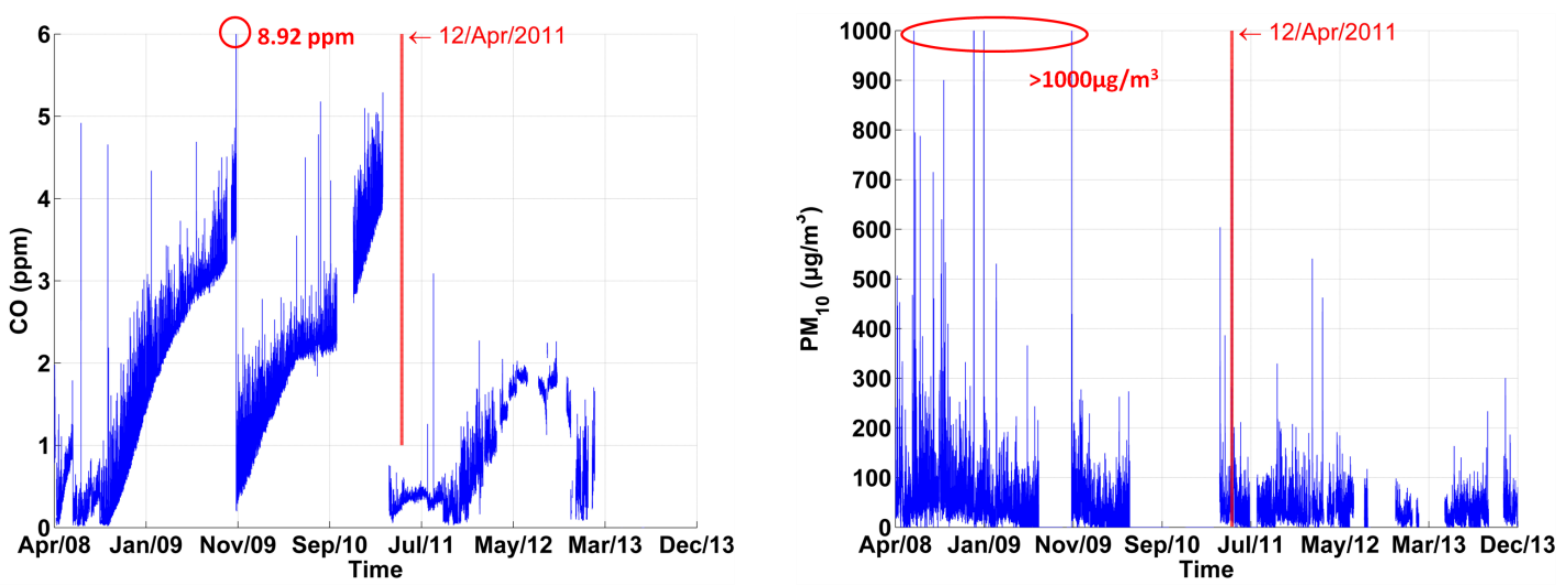

Fig. 2: The time series data (of hourly values) of the meteorological variables and the major criteria pollutant concentrations over the period extending from $1^{\text {st }}$ April 2008 to $31^{\text {st }}$ December 2013:(a) Ambient Temperature $\left({ }^{\circ} \mathrm{C}\right)$, (b) Solar radiation $\left(\mathrm{W} / \mathrm{m}^{2}\right)$, (c) Relative humidity (\%), (d) Rain fall (mm), (e) Wind Speed (m/s), (f) NOx (ppb), (g) CO (ppm), (h) $\mathrm{PM}_{10}\left(\mu \mathrm{g} / \mathrm{m}^{3}\right)$. Vertical red line depicts the time of AQMS relocation.

Citation details: Mouzourides, P., Kumar, P., Neophytou M.K., 2015. Assessment of long-term measurements of particulate matter and gaseous pollutants in South-East Mediterranean. Atmospheric Environment 107, 148-165. [Online link] 
(a)

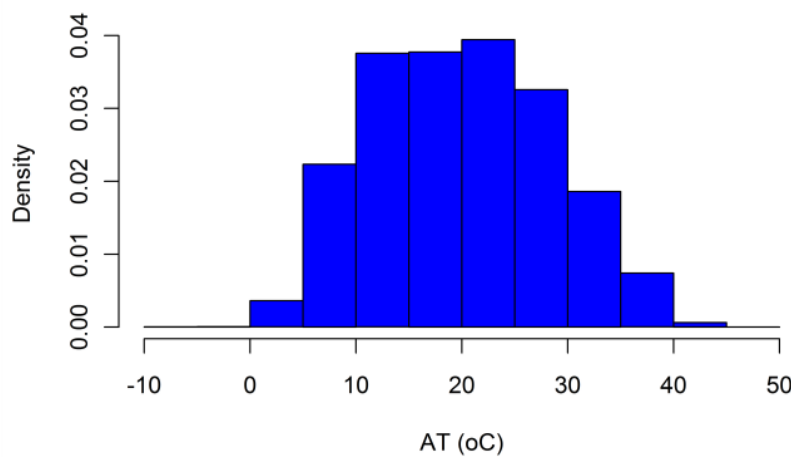

(c)

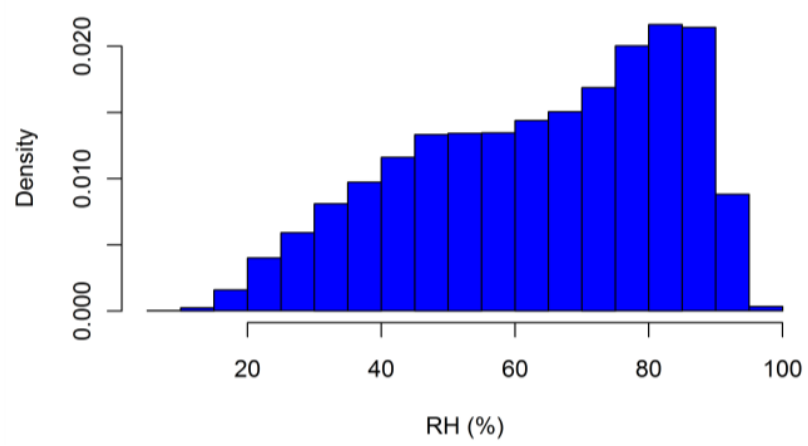

(e)

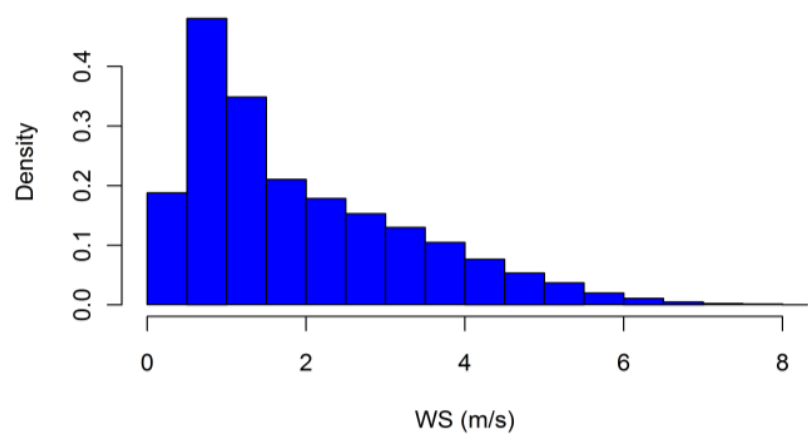

$(\mathrm{g})$

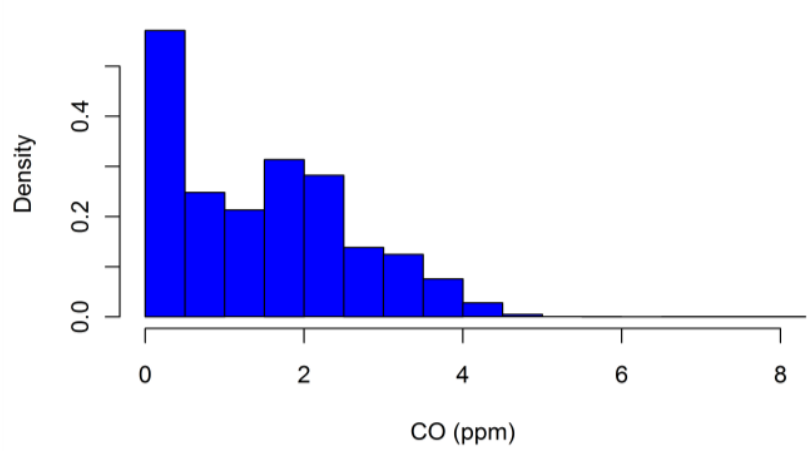

(b)

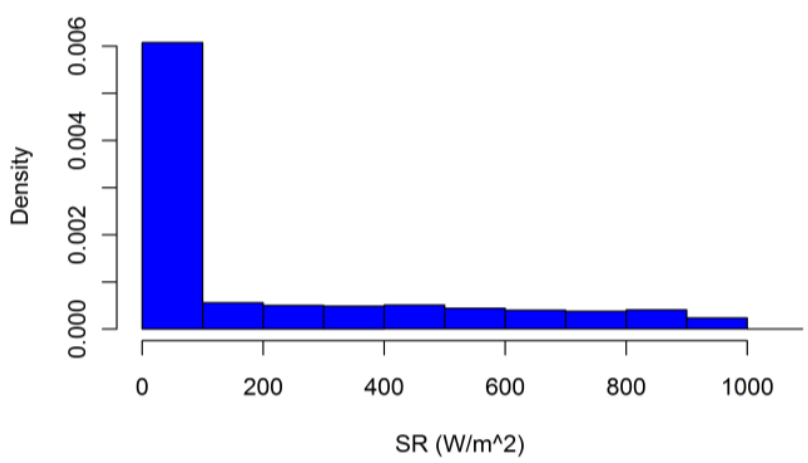

(d)

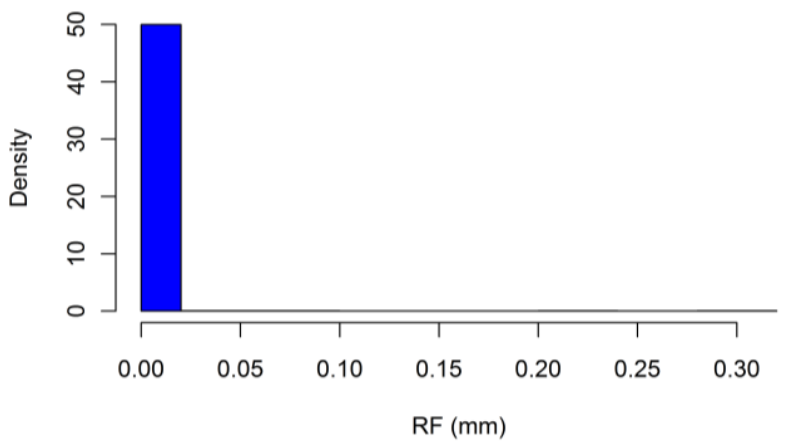

(f)

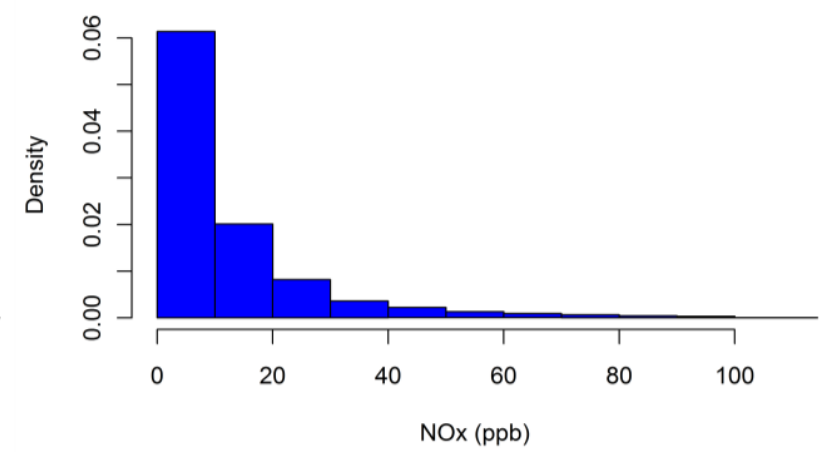

(h)

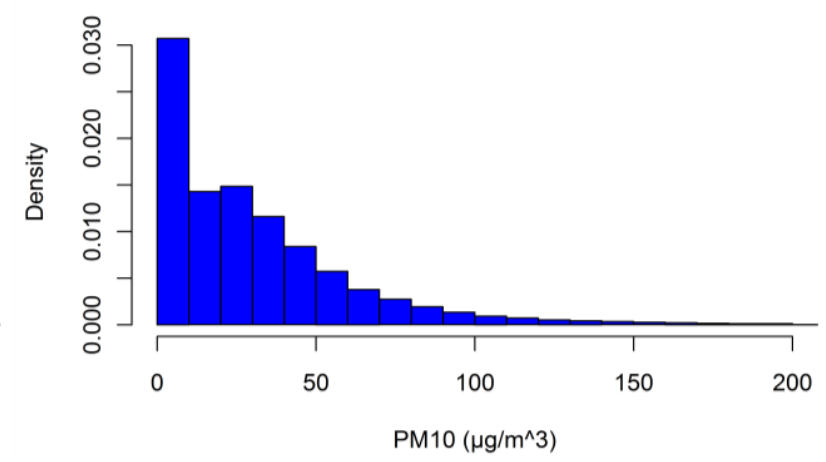

Fig. 3: Histograms of meteorological parameters and air quality concentrations over the period extending from $1^{\text {st }}$ April 2008 to $31^{\text {st }}$ December 2013. Hourly values were used for (a) Ambient Temperature $\left({ }^{\circ} \mathrm{C}\right)$ (b) Solar radiation $\left(\mathrm{W} / \mathrm{m}^{2}\right)$ (c) Relative humidity (\%) (d) Rain fall (mm) (e) Wind Speed (m/s), (f) NOx (ppb) (g) CO (ppm) (h) $\mathrm{PM}_{10}\left(\mu \mathrm{g} / \mathrm{m}^{3}\right)$. measurements of particulate matter and gaseous pollutants in South-East Mediterranean. Atmospheric Environment 107, 148-165. [Online link] 


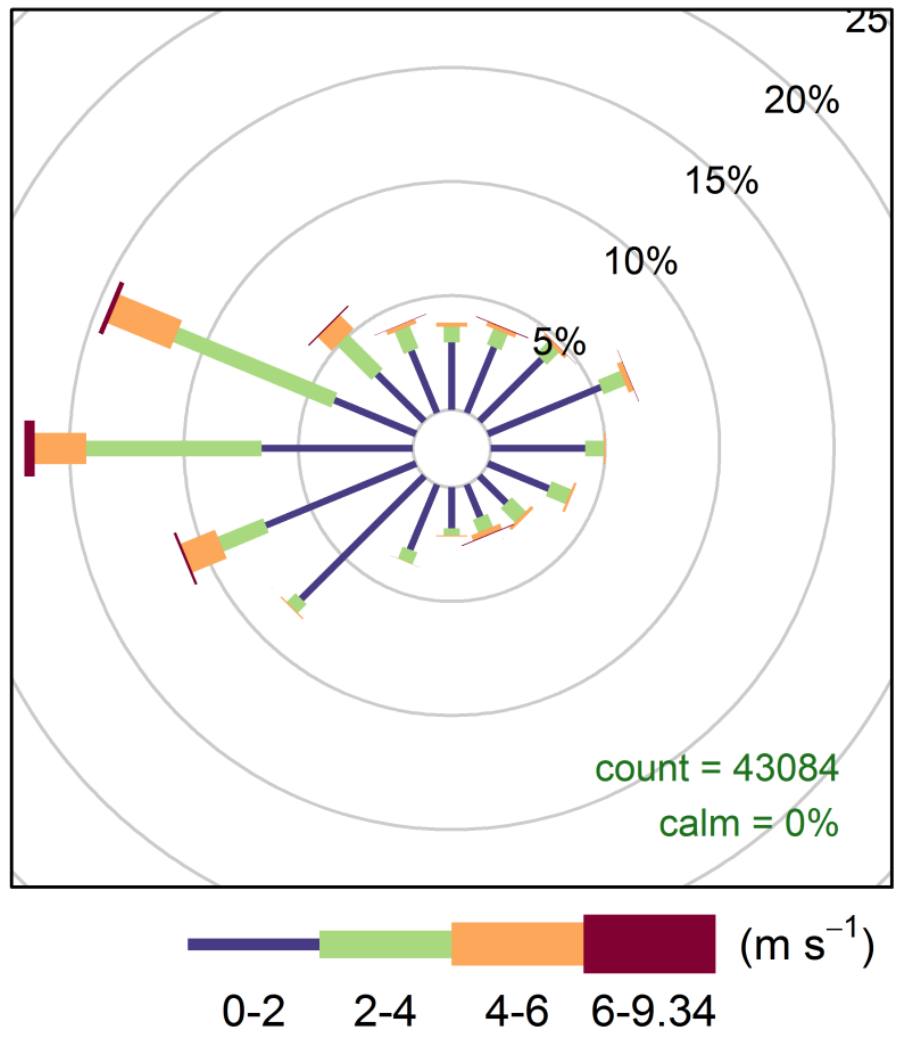

Fig. 4: Wind rose diagram of the Wind speed $(\mathrm{m} / \mathrm{s})$ and Wind Directions $\left(^{\circ}\right)$ over the measurement period extending from $1^{\text {st }}$ April 2008 to $31^{\text {st }}$ December 2013 using hourly data.

Citation details: Mouzourides, P., Kumar, P., Neophytou M.K., 2015. Assessment of long-term measurements of particulate matter and gaseous pollutants in South-East Mediterranean. Atmospheric Environment 107, 148-165. [Online link] 


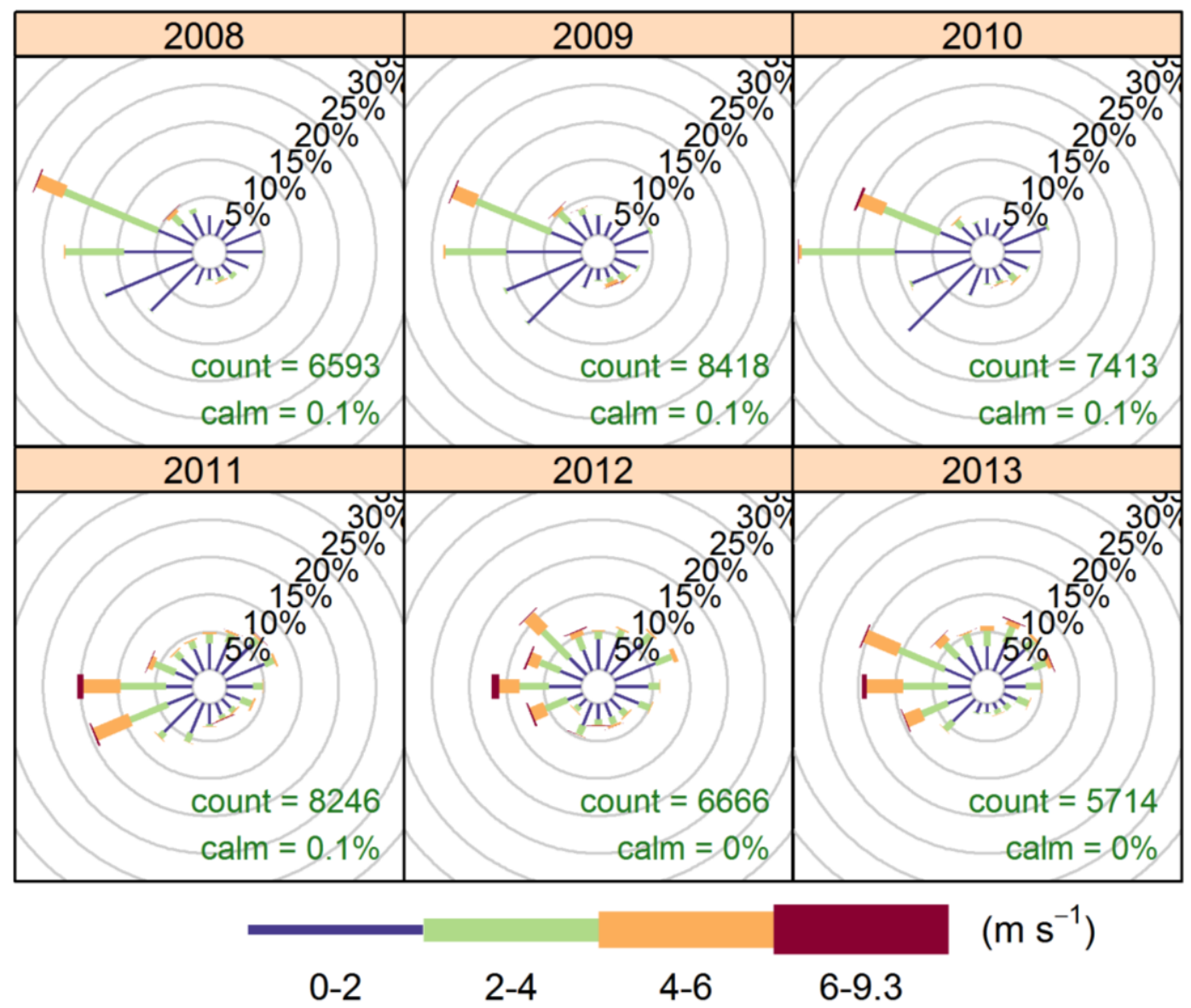

Fig. 5: Wind rose diagrams depict the hourly frequency distribution from top left to bottom right for 2008, 2009, 2010, 2011, 2012 and 2013.

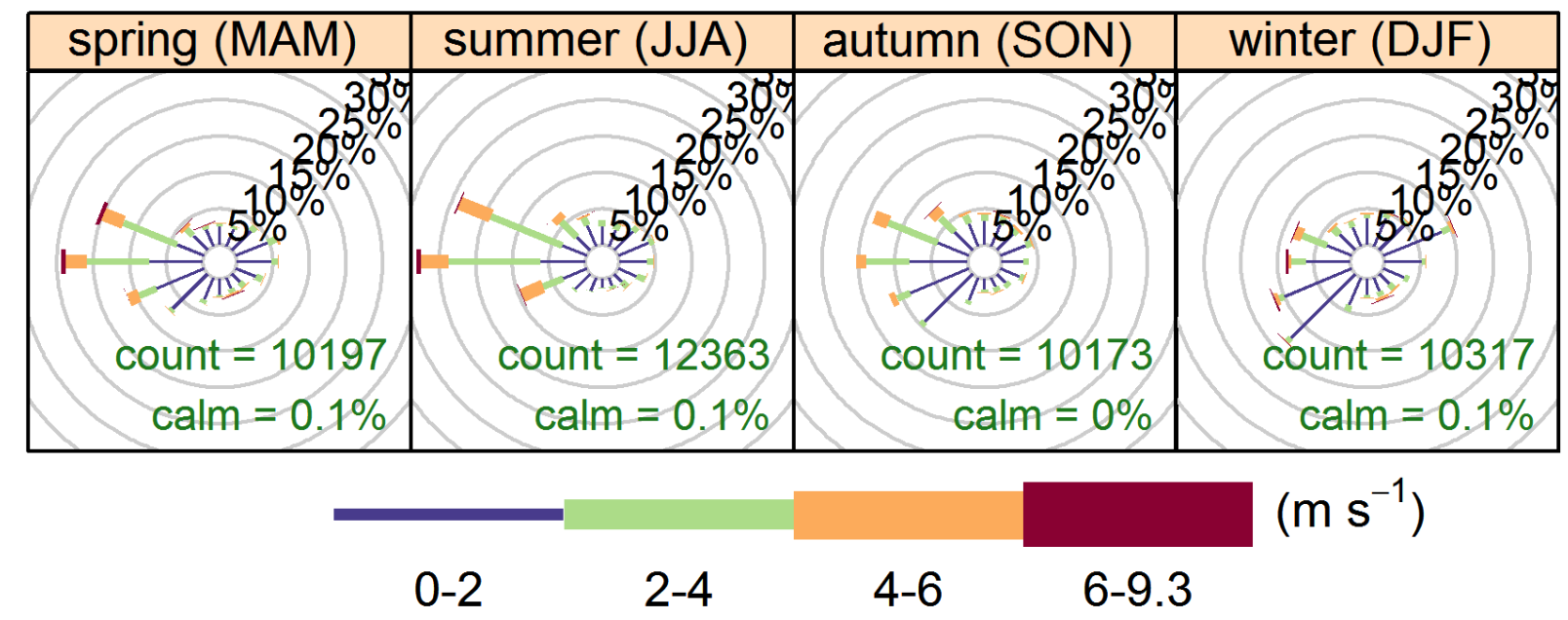

Fig. 6: Wind rose diagrams for hourly values of the wind direction and wind speed during (from left to right) spring, summer, autumn and winter sessions over the measurement period of $1^{\text {st }}$ April 2008 to $31^{\text {st }}$ December 2013.

Citation details: Mouzourides, P., Kumar, P., Neophytou M.K., 2015. Assessment of long-term measurements of particulate matter and gaseous pollutants in South-East Mediterranean. Atmospheric Environment 107, 148-165. [Online link] 
(a)

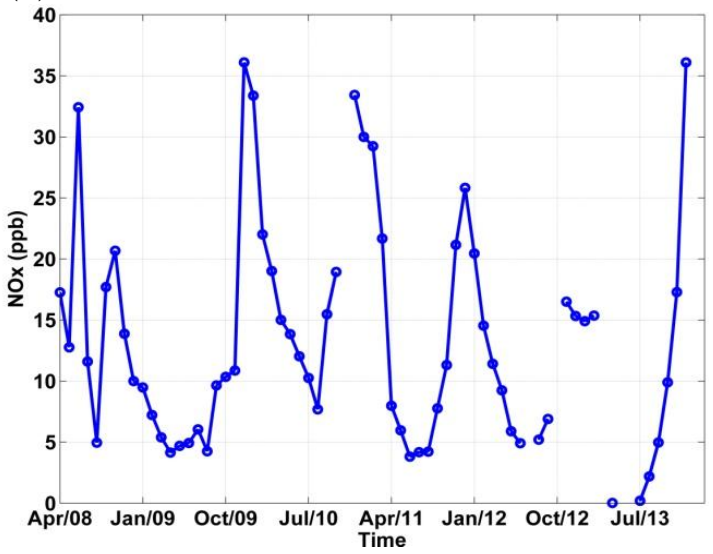

(c)

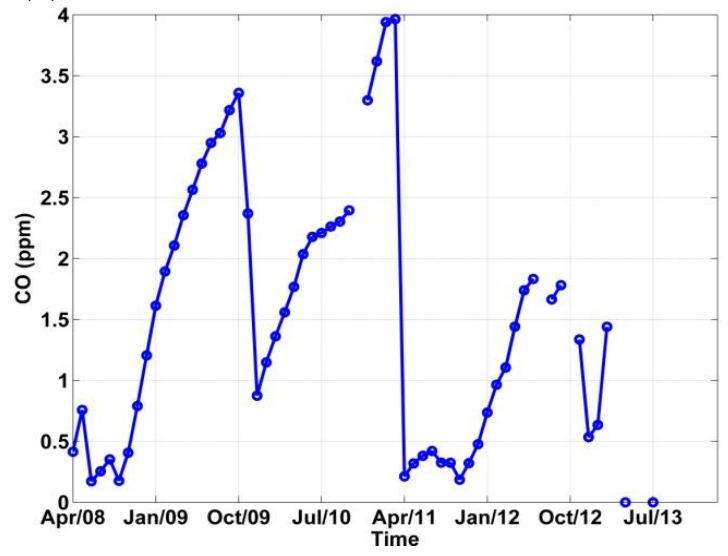

(e)

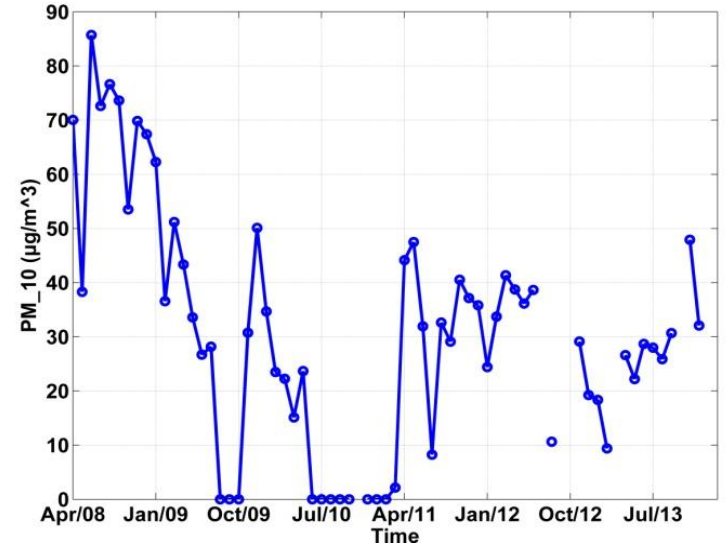

(b)

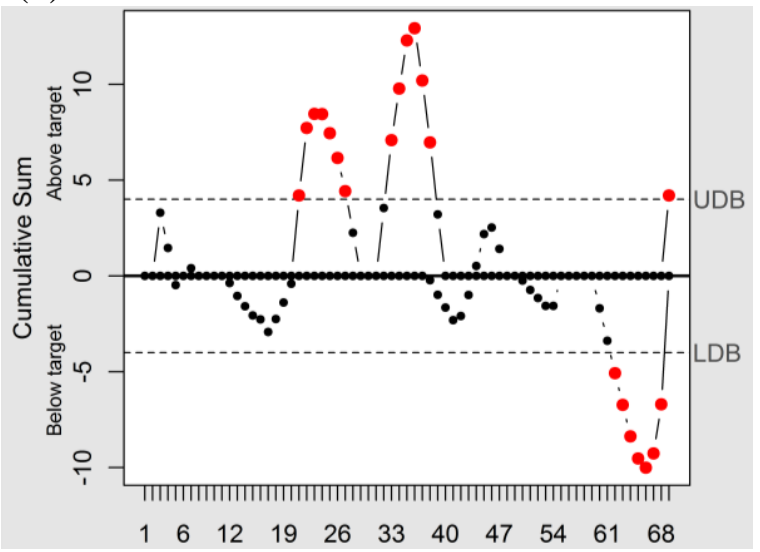

(d)

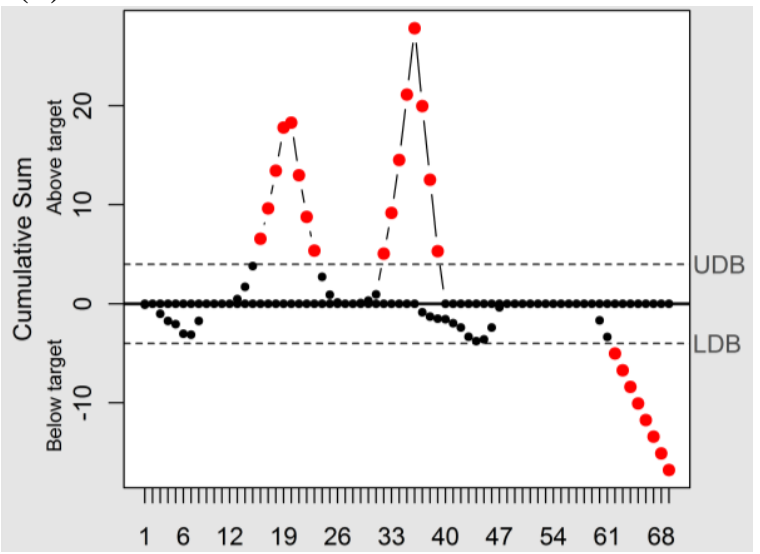

(f)

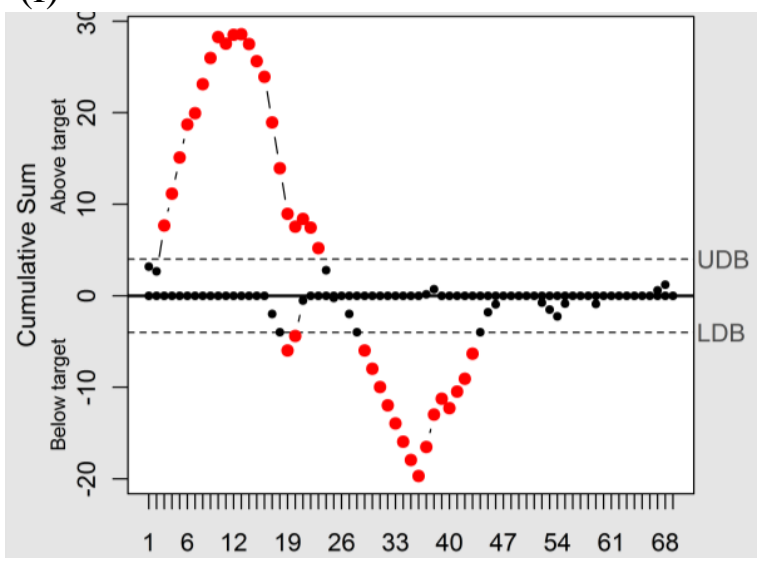

Fig. 7: Plots in the left column show the monthly variation of (a) NOx, (c) CO, and (e) $\mathrm{PM}_{10}$ concentrations from 2008 to 2013. The plots in the right column present the corresponding CUSUM results for each pollutant - the horizontal axis represents the month in the analysis where number 1 stands for April of 2008 and number 69 stands for December 2013. UDB and LDB stand for Upper and Lower Decision Boundaries, respectively. 


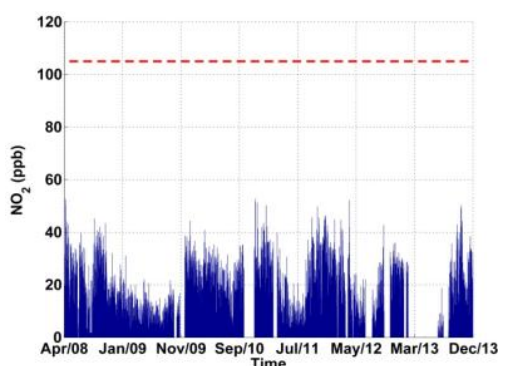

(a)

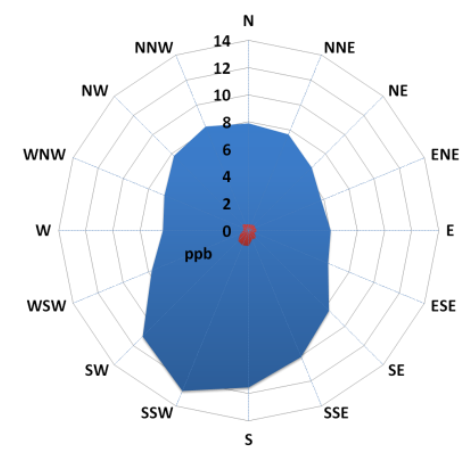

(d)

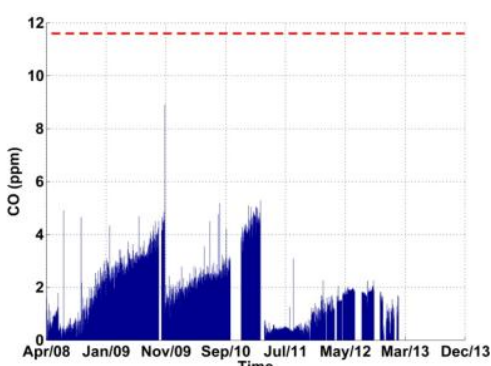

(b)

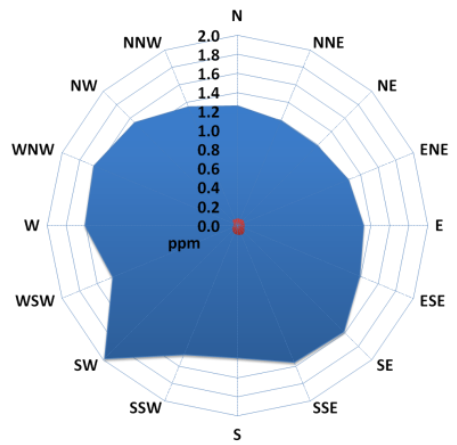

(e)

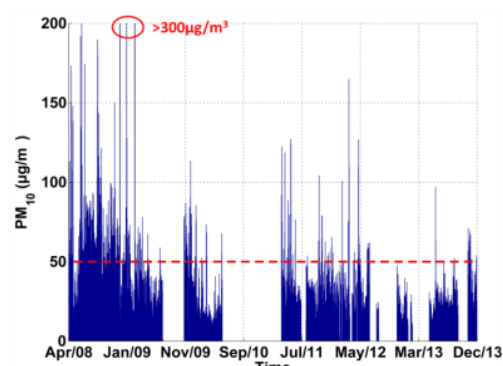

(c)

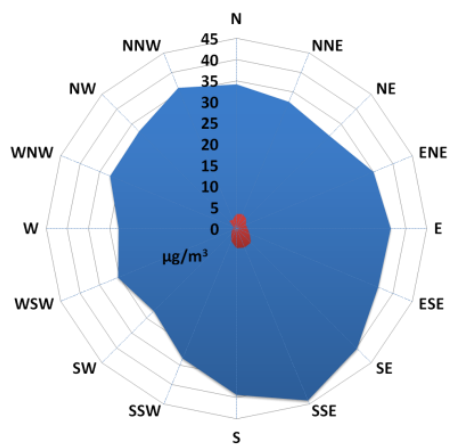

(f)

Fig. 8: The time series of pollutants concentration for hourly average values of (a) $\mathrm{NO}_{2}$ (ppb), (b) $\mathrm{CO}(\mathrm{ppm})$ - hourly average values, and (c) $\mathrm{PM}_{10}\left(\mu \mathrm{g} / \mathrm{m}^{3}\right)$ - daily average values (due to EU Directive daily limit), all in blue. The horizontal red lines depict the corresponding limit values of European Union Directive. The average values of pollutants (d) $\mathrm{NO}_{2}$, (e) $\mathrm{CO}$, (f) $\mathrm{PM}_{10}$ (all in blue) for 16 primary wind direction sectors during the period of $1^{\text {st }}$ April 2008 to $31^{\text {st }}$ December 2013. The red circle in each of (d), (e),(f) depicts the minimum average concentration for the same 16 primary wind direction sectors. 


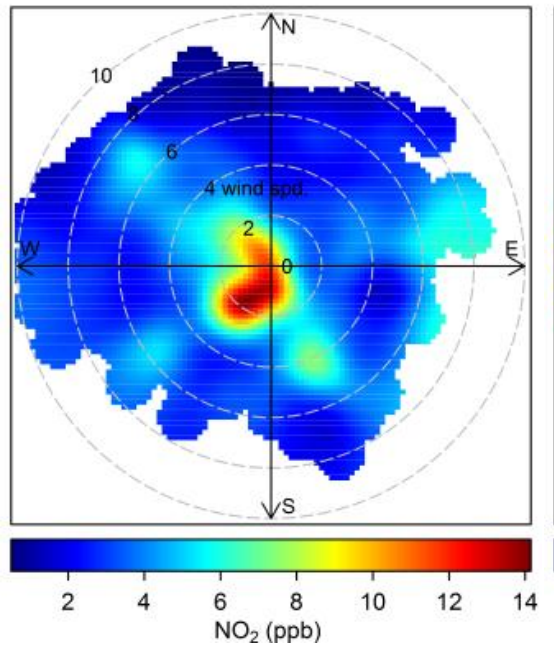

(a)

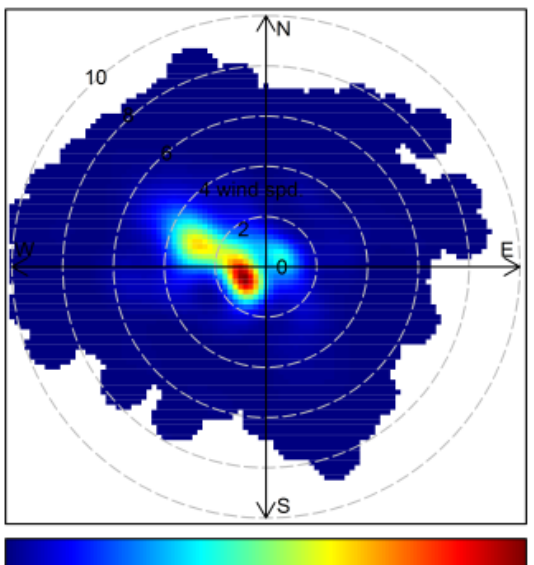

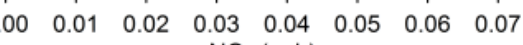

(d)

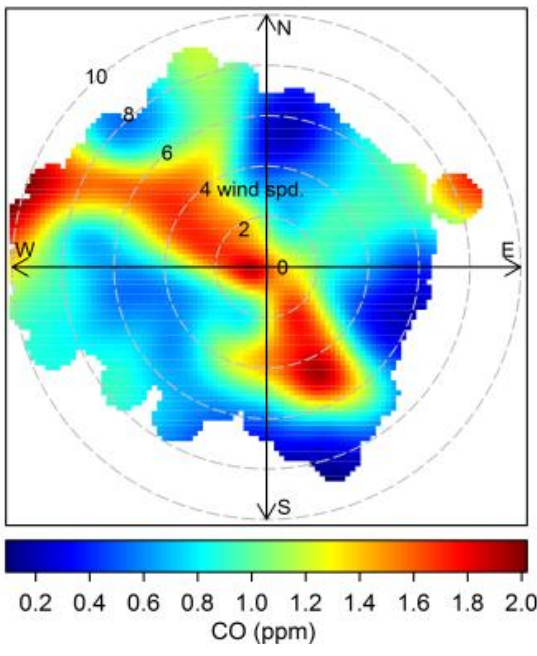

(b)

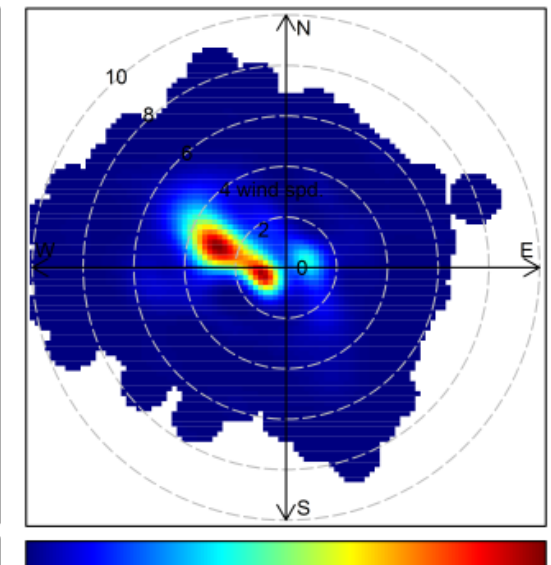

0000.0020 .0040 .0060 .0080 .0100 .0120 .014 $\mathrm{CO}(\mathrm{ppm})$

(e)

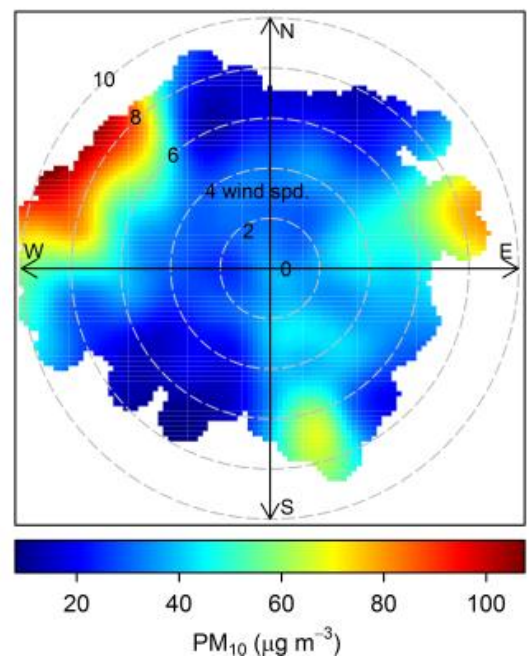

(c)

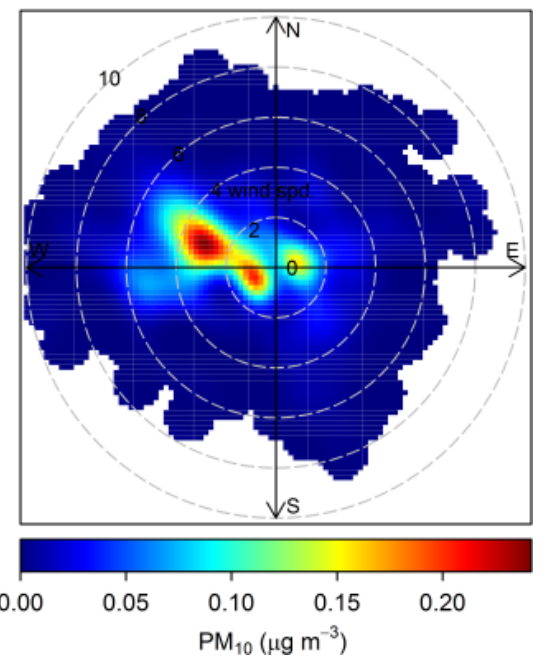

(f)

Fig. 9: Bivariate polar plots for (a) $\mathrm{NO}_{2}$, (b) $\mathrm{CO}$, (c) $\mathrm{PM}_{10}$ (hourly average values were used for all pollutants).These plots present as smoothed surfaces (Optimal visualization) how concentrations vary depending on the local wind speed and wind direction. Bivariate-polar-plot surfaces are smoothed in order to provide an indication of the overall pattern, so color bar does not represent the real measurements values. Bivariate polar plots (d) $\mathrm{NO}_{2}$, (e) $\mathrm{CO}$, (f) $\mathrm{PM}_{10}$ represent the same measurements in a different way. All wind speed-direction bins were multiplied by frequency of occurrence in order to highlight the main and different sources that dominate the overall mean concentration.

Citation details: Mouzourides, P., Kumar, P., Neophytou M.K., 2015. Assessment of long-term measurements of particulate matter and gaseous pollutants in South-East Mediterranean. Atmospheric Environment 107, 148-165. [Online link] 


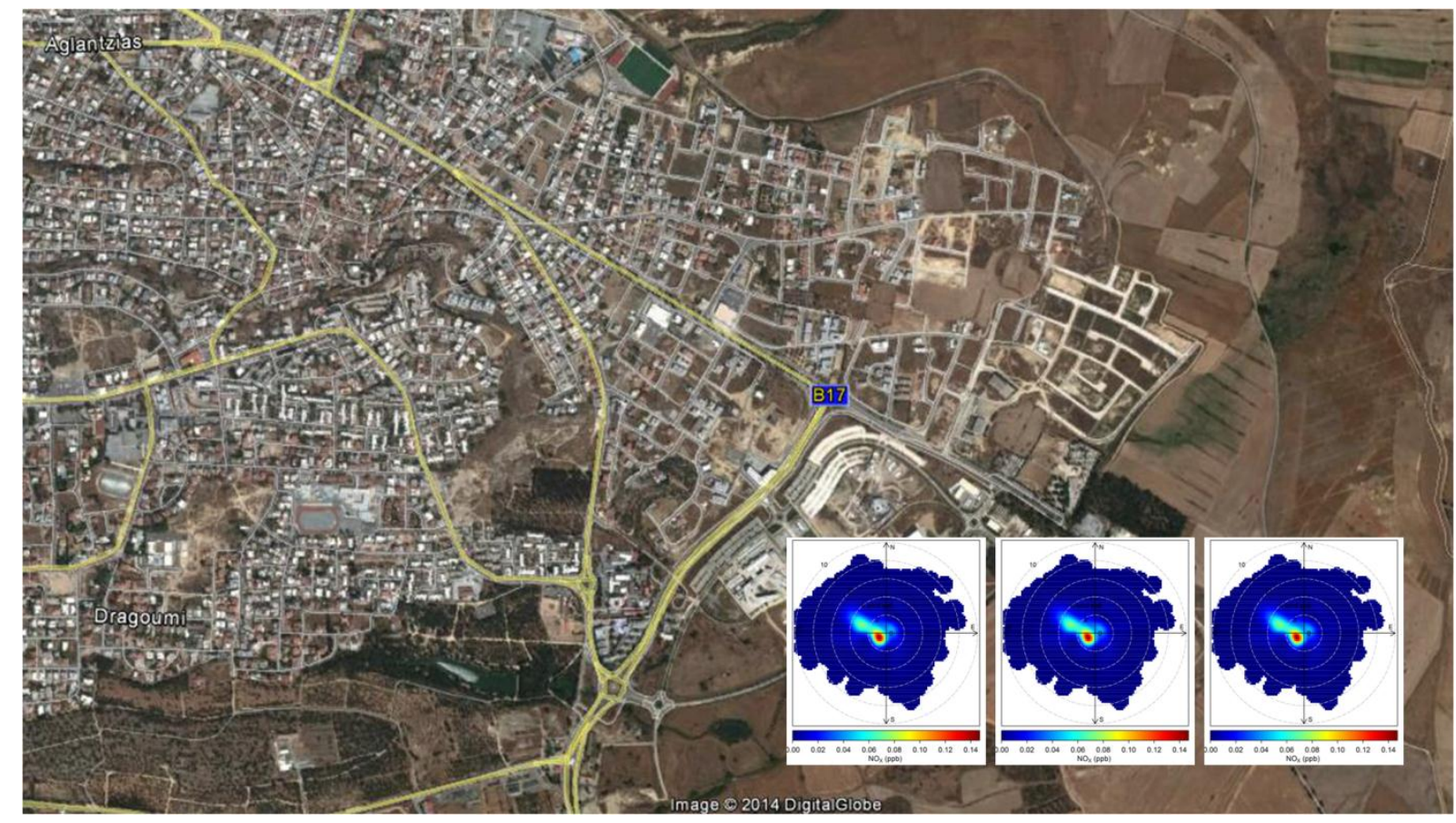

Fig. 10: The study area with the bivariate polar plots of criteria pollutants $\left(\mathrm{NOx}, \mathrm{CO}, \mathrm{PM}_{10}\right)$ for visualization of emission sources.

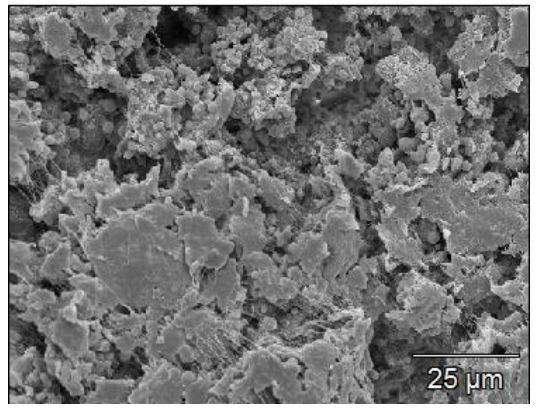

(a)

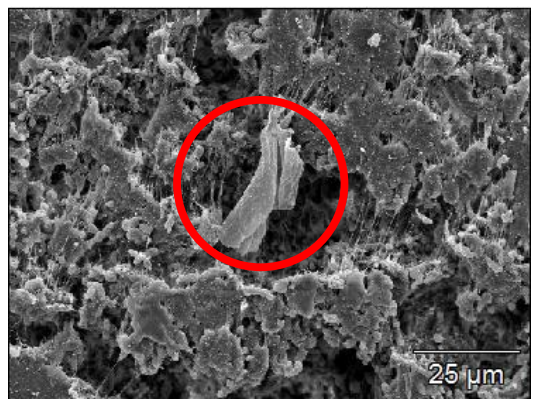

(d)

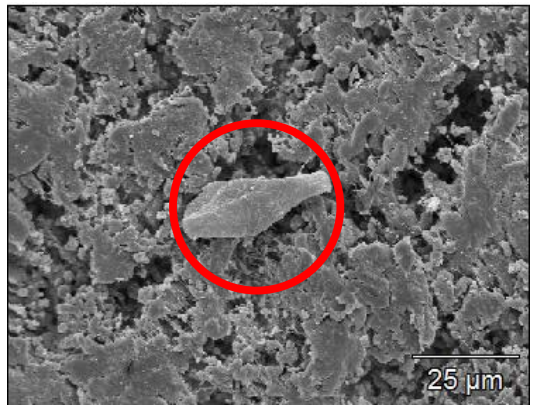

(b)

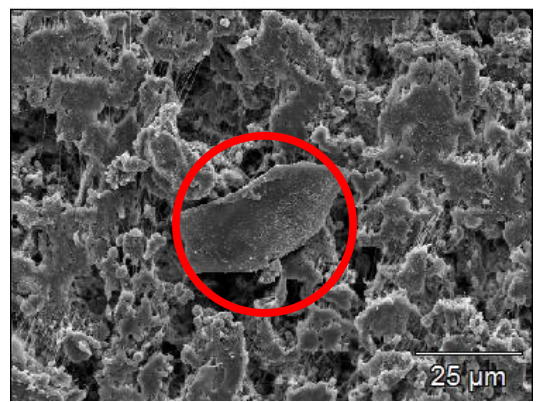

(e)

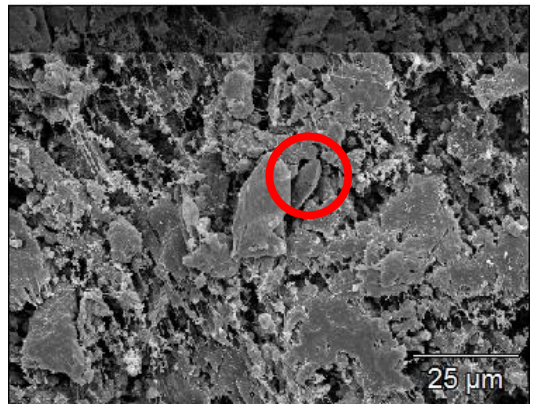

(c)

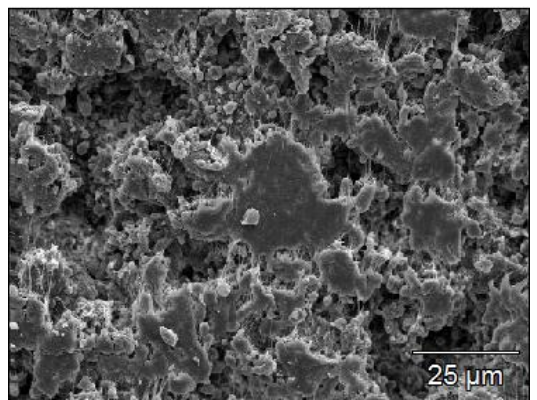

(f)

Fig. 11: PTFE filters showing (a) clean (blank) surface having amorphous and heterogeneous structure, (b-f) samples with collected pollutant mass. The images show airborne particles in different shapes and dimensions. Red circles show particles with dimensions larger than $10 \mu \mathrm{m}$.

Citation details: Mouzourides, P., Kumar, P., Neophytou M.K., 2015. Assessment of long-term measurements of particulate matter and gaseous pollutants in South-East Mediterranean. Atmospheric Environment 107, 148-165. [Online link] 
28 May. 2010
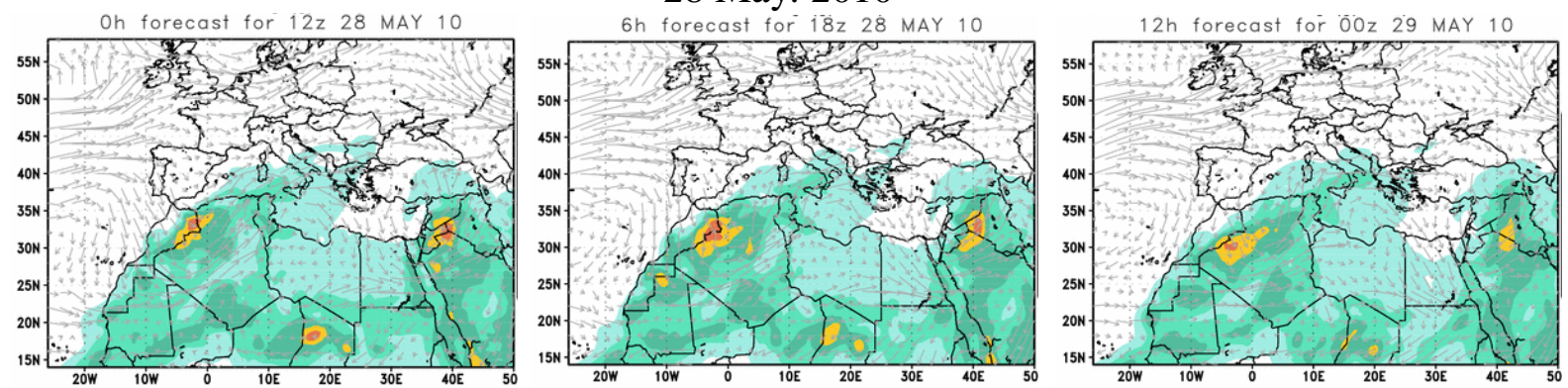

29 May. 2010
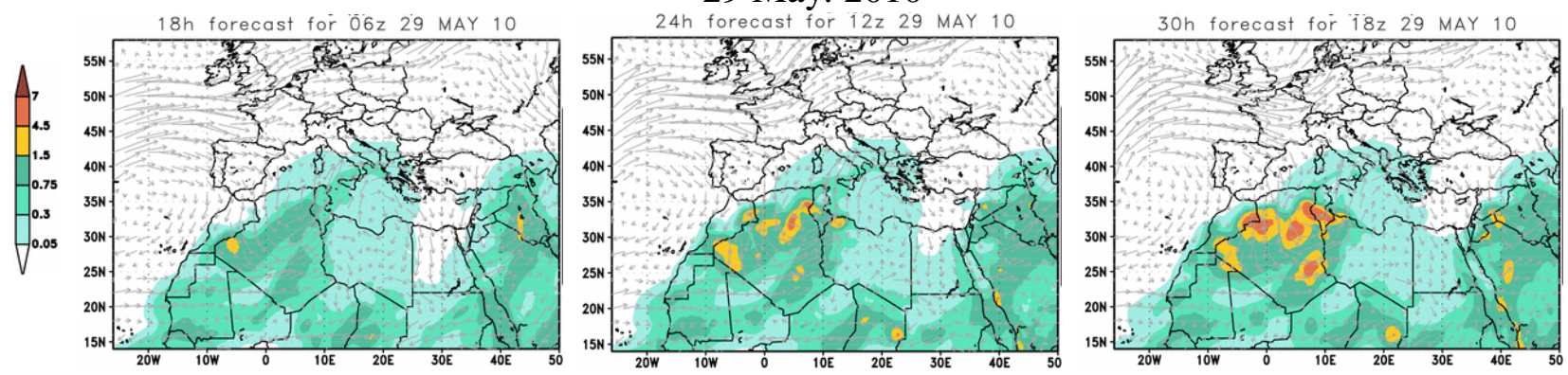

30 May. 2010
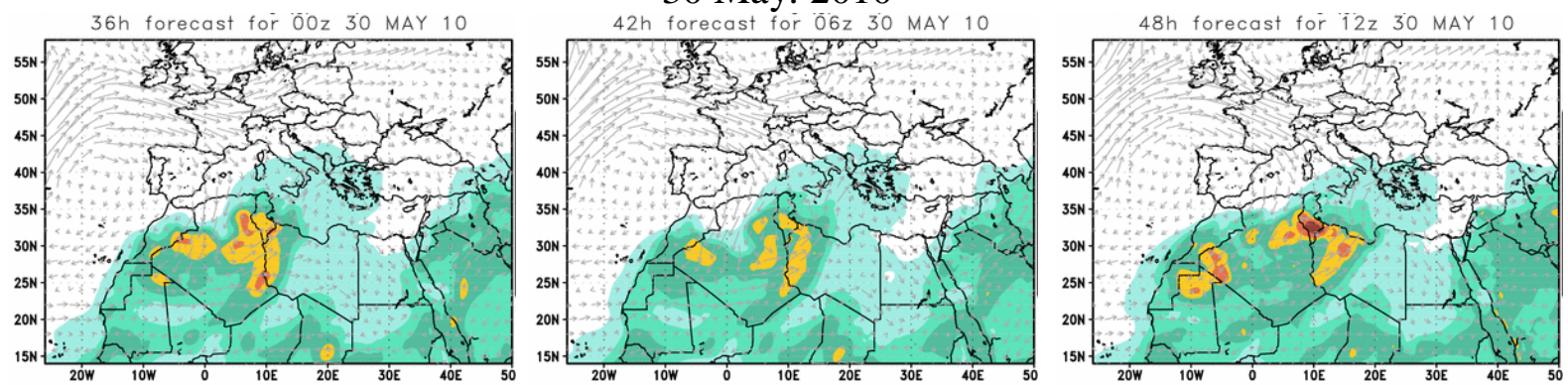

Fig. 12: Dust load $\left(\mathrm{g} / \mathrm{m}^{2}\right)$ at $3000 \mathrm{~m}$ over Mediterranean sea according to DREAM model. The evolution of dust transport phenomena from $28^{\text {th }}$ May 2010 until $30^{\text {th }}$ May 2010. DREAM model yields a prediction every six hours.

Citation details: Mouzourides, P., Kumar, P., Neophytou M.K., 2015. Assessment of long-term measurements of particulate matter and gaseous pollutants in South-East Mediterranean. Atmospheric Environment 107, 148-165. [Online link] 
24 Jan. 2009
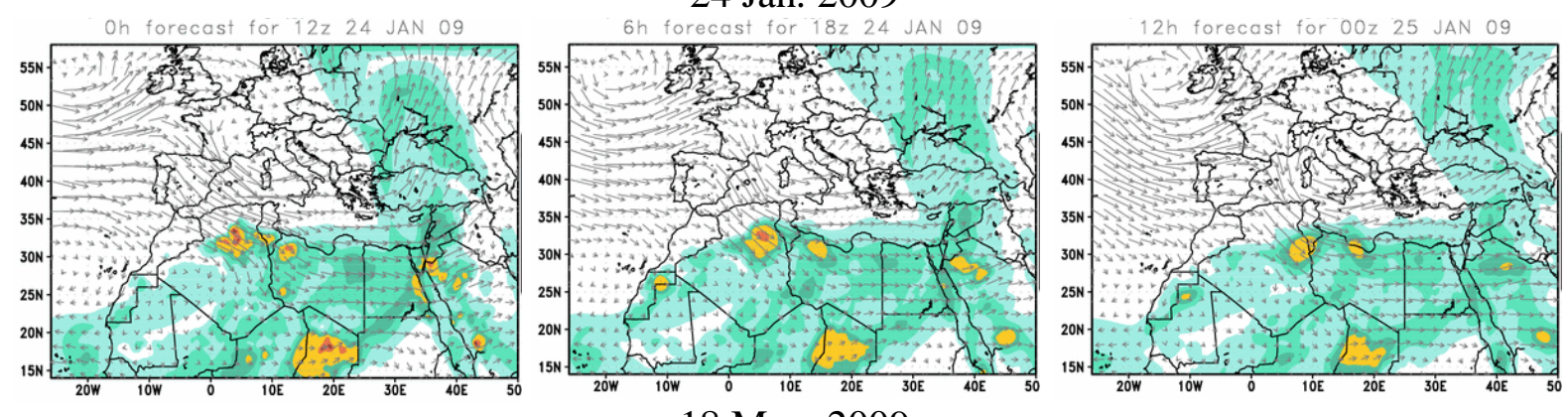

18 May. 2009
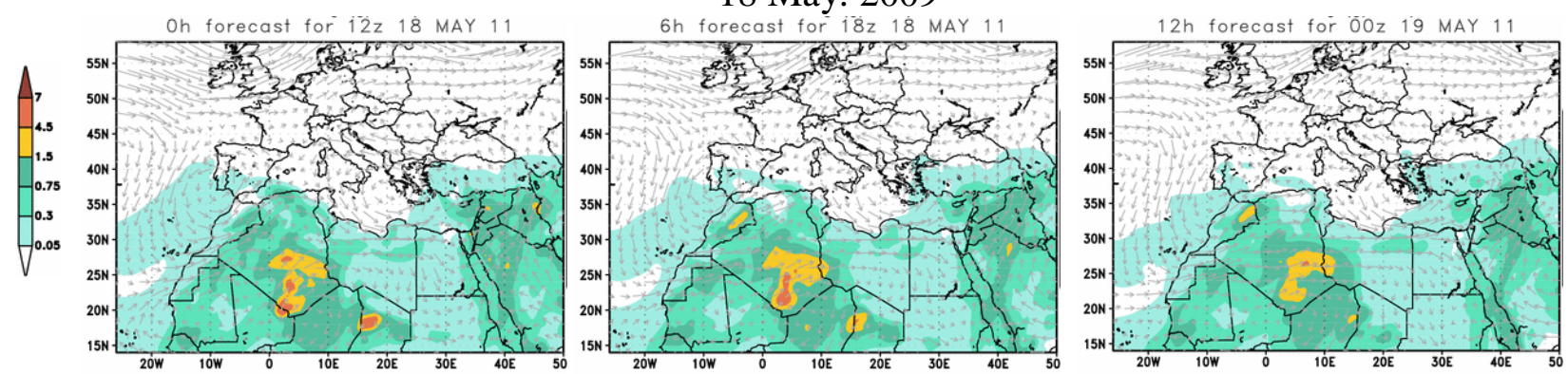

20 Jun. 2012
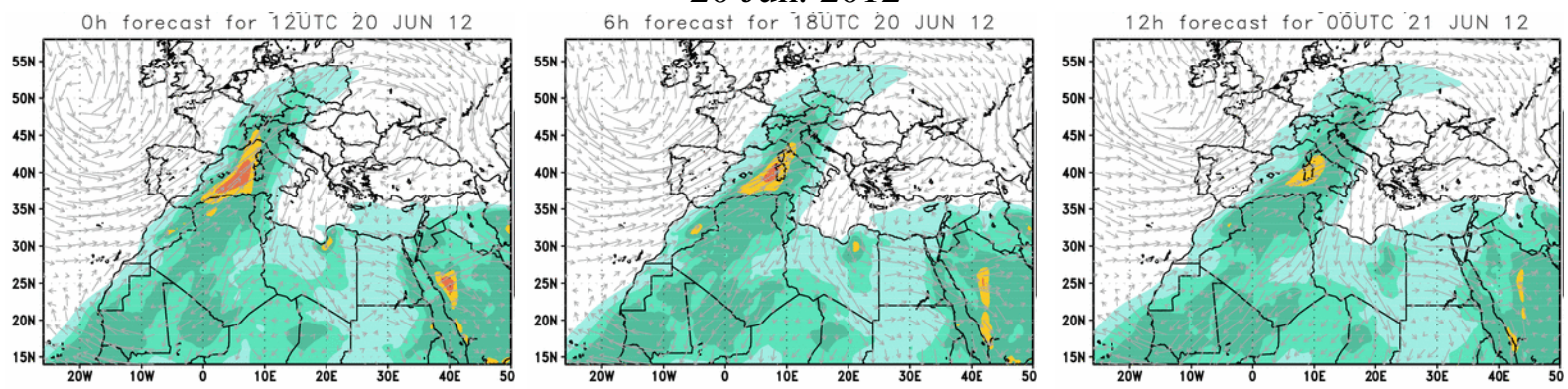

Fig. 13: Dust load $\left(\mathrm{g} / \mathrm{m}^{2}\right)$ at $3000 \mathrm{~m}$ over Mediterranean sea according to DREAM model. The evolution of dust transport phenomena during days of $24^{\text {th }}$ January 2009 (up row) and $18^{\text {th }}$ May 2009 (middle row) and $20^{\text {th }}$ June 2012.

Citation details: Mouzourides, P., Kumar, P., Neophytou M.K., 2015. Assessment of long-term measurements of particulate matter and gaseous pollutants in South-East Mediterranean. Atmospheric Environment 107, 148-165. [Online link] 


\title{
Supplementary Materials
}

\section{Assessment of long-term measurements of particulate matter and gaseous pollutants in Southern-Eastern Mediterranean: the case of Nicosia, Cyprus}

\author{
Petros Mouzourides ${ }^{1}$, Prashant Kumar ${ }^{2,3}$, Marina Neophytou K.-A. ${ }^{1 \dagger}$ \\ ${ }^{1}$ Environmental Fluid Mechanics Laboratory, Department of Civil and Environmental \\ Engineering, University of Cyprus, Nicosia, Cyprus \\ ${ }^{2}$ Department of Civil and Environmental Engineering, Faculty of Engineering and Physical \\ Sciences (FEPS), University of Surrey, Guildford GU2 7XH, United Kingdom \\ ${ }^{3}$ Environmental Flow (EnFlo) Research Centre, FEPS, University of Surrey, Guildford GU2 \\ 7XH, United Kingdom
}

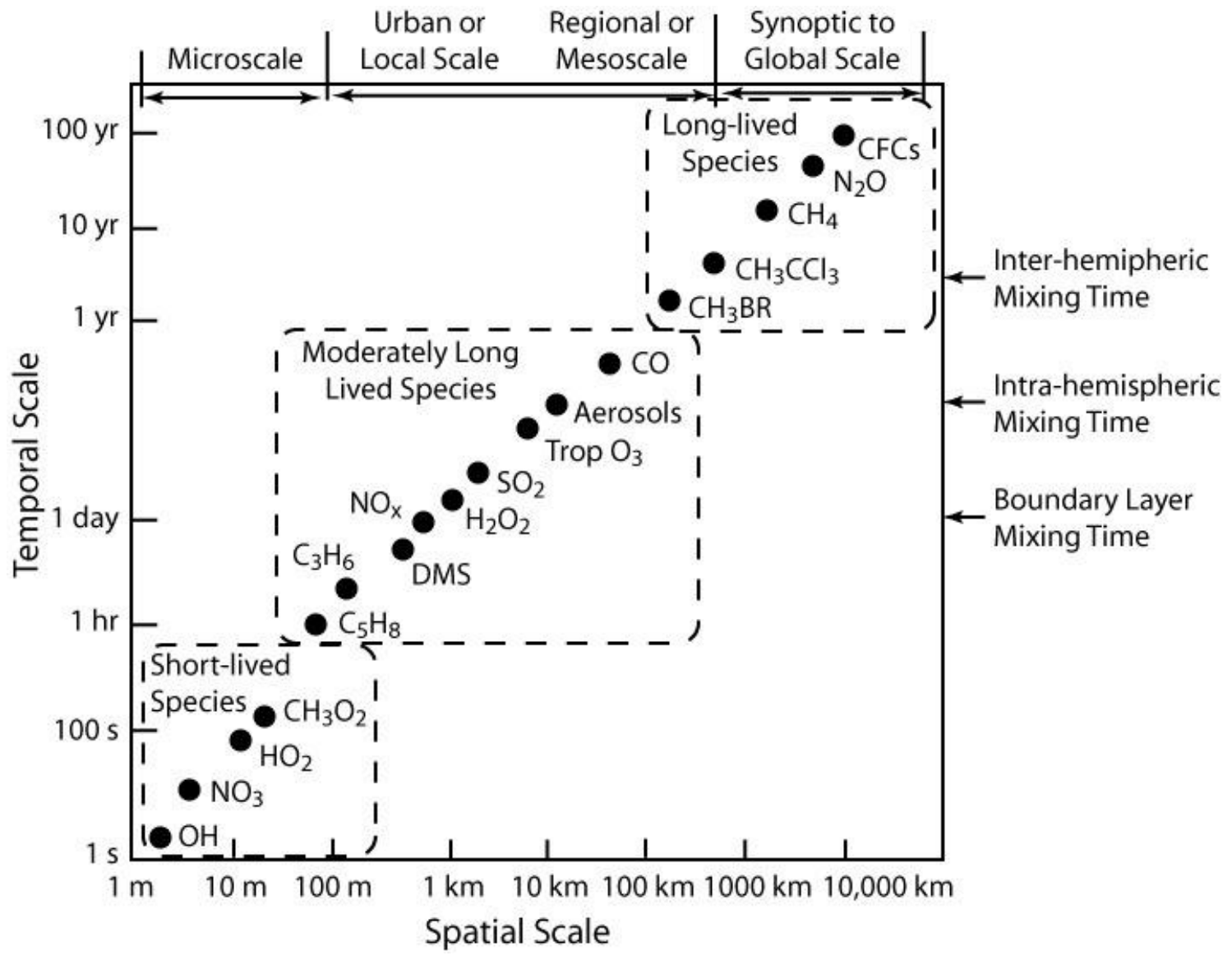

\footnotetext{
${ }^{\dagger}$ Corresponding author: neophytou@ucy.ac.cy

Citation details: Mouzourides, P., Kumar, P., Neophytou M.K., 2015. Assessment of long-term measurements of particulate matter and gaseous pollutants in South-East Mediterranean. Atmospheric Environment 107, 148-165. [Online link]
} 
Figure S1: Spatial and temporal scales of variability for atmospheric constituents (Seinfeld and Pandis, 2012).

Table S1: Standards and Guidelines of the criteria urban air pollutants (CO, NOx and $\left.\mathrm{PM}_{10}\right)$.

\begin{tabular}{|c|c|c|c|c|c|}
\hline Pollutant & Concentration & $\begin{array}{c}\text { Averaging } \\
\text { period }\end{array}$ & Legal nature & $\begin{array}{c}\text { Permitted } \\
\text { exceedences } \\
\text { each year } \\
\end{array}$ & Description \\
\hline $\begin{array}{c}\text { Carbon } \\
\text { monoxide } \\
(\mathrm{CO})\end{array}$ & $\begin{array}{c}10 \mathrm{mg} / \mathrm{m}^{3} \\
(11.6 \mathrm{ppm})\end{array}$ & $\begin{array}{l}\text { Maximum } \\
\text { daily } 8 \text { hour } \\
\text { mean }\end{array}$ & $\begin{array}{c}\text { Limit value } \\
\text { entered into } \\
\text { force } \\
1.1 .2005 \\
\end{array}$ & $\mathrm{n} / \mathrm{a}$ & $\begin{array}{l}\text { Limit value for } \\
\text { the protection } \\
\text { of human } \\
\text { health }\end{array}$ \\
\hline \multirow{3}{*}{$\begin{array}{c}\text { Nitrogen } \\
\text { dioxide } \\
\left(\mathrm{NO}_{2}\right)\end{array}$} & $\begin{array}{c}200 \mu \mathrm{g} / \mathrm{m}^{3} \\
(105 \mathrm{ppb})\end{array}$ & 1 hour & $\begin{array}{l}\text { Limit value } \\
\text { entered into } \\
\text { force } \\
1.1 .2010\end{array}$ & 18 & $\begin{array}{c}\text { Limit value for } \\
\text { the protection } \\
\text { of human } \\
\text { health }\end{array}$ \\
\hline & $\begin{array}{c}40 \mu \mathrm{g} / \mathrm{m}^{3} \\
(21 \mathrm{ppb})\end{array}$ & 1 year & $\begin{array}{l}\text { Limit value } \\
\text { entered into } \\
\text { force } \\
1.1 .2010\end{array}$ & $\mathrm{n} / \mathrm{a}$ & $\begin{array}{c}\text { Limit value for } \\
\text { the protection } \\
\text { of human } \\
\text { health }\end{array}$ \\
\hline & $\begin{array}{c}30 \mu \mathrm{g} / \mathrm{m}^{3} \\
(16 \mathrm{ppb})\end{array}$ & 1 year & $\begin{array}{l}\text { Limit value } \\
\text { entered into } \\
\text { force } \\
1.1 .2010 \\
\end{array}$ & $\mathrm{n} / \mathrm{a}$ & $\begin{array}{l}\text { Limit value for } \\
\text { the protection } \\
\text { of vegetation }\end{array}$ \\
\hline \multirow{2}{*}{$\mathbf{P M}_{10}$} & $50 \mu \mathrm{g} / \mathrm{m}^{3}$ & 24 hours & $\begin{array}{l}\text { Limit value } \\
\text { entered into } \\
\text { force } \\
1.1 .2005\end{array}$ & 35 & $\begin{array}{l}\text { Limit value for } \\
\text { the protection } \\
\text { of human } \\
\text { health }\end{array}$ \\
\hline & $40 \mu \mathrm{g} / \mathrm{m}^{3}$ & 1 year & $\begin{array}{l}\text { Limit value } \\
\text { entered into } \\
\text { force } \\
1.1 .2005\end{array}$ & $\mathrm{n} / \mathrm{a}$ & $\begin{array}{l}\text { Limit value for } \\
\text { the protection } \\
\text { of human } \\
\text { health }\end{array}$ \\
\hline
\end{tabular}

Citation details: Mouzourides, P., Kumar, P., Neophytou M.K., 2015. Assessment of long-term measurements of particulate matter and gaseous pollutants in South-East Mediterranean. Atmospheric Environment 107, 148-165. [Online link] 
Table S2: Natural and anthropogenic sources of criteria pollutants $\left(\mathrm{CO}, \mathrm{NOx}\right.$ and $\left.\mathrm{PM}_{10}\right)$.

\begin{tabular}{|c|c|c|c|c|}
\hline \multirow[t]{2}{*}{ Compounds } & \multirow[t]{2}{*}{ Natural sources } & \multirow{2}{*}{$\begin{array}{l}\text { Anthropogenic } \\
\text { sources }\end{array}$} & \multicolumn{2}{|c|}{ Scales } \\
\hline & & & Spatial & $\begin{array}{l}\text { Temporal } \\
\text { (Average } \\
\text { Residence time) } \\
\end{array}$ \\
\hline \multirow[t]{4}{*}{$\begin{array}{c}\text { CO } \\
\text { (Carbon } \\
\text { Monoxide) }\end{array}$} & Forest fires & $\begin{array}{l}\text { Incomplete } \\
\text { combustion of fossil } \\
\text { fuels and wood }\end{array}$ & $\begin{array}{l}100 \mathrm{Km} \\
\text { (Regional Scale) }\end{array}$ & 6-9 months \\
\hline & $\begin{array}{l}\text { Atmospheric } \\
\text { oxidation of } \\
\text { natural } \\
\text { hydrocarbons and } \\
\text { methane }\end{array}$ & Motor vehicles & & \\
\hline & & $\begin{array}{l}\text { Oxidation of } \\
\text { hydrocarbons }\end{array}$ & & \\
\hline & & $\begin{array}{l}\text { Industrial processes } \\
\text { blast furnaces }\end{array}$ & & \\
\hline \multirow{3}{*}{$\begin{array}{c}\text { NOx } \\
\text { (Nitogen } \\
\text { Oxides) }\end{array}$} & Forest fires & $\begin{array}{l}\text { Combustion of oil. } \\
\text { gas. and coal }\end{array}$ & $\begin{array}{l}1 \mathrm{Km} \\
\text { (Urban Scale) }\end{array}$ & 1 day \\
\hline & $\begin{array}{l}\text { Anaerobic } \\
\text { processes in soil }\end{array}$ & $\begin{array}{l}\text { Atmospheric } \\
\text { transformation of } \\
\text { NO }\end{array}$ & & \\
\hline & Electric storms & & & \\
\hline \multirow{6}{*}{$\begin{array}{l}\text { Particulate } \\
\text { Matter }\end{array}$} & Mineral dust & Industrial dust & $10 \mathrm{Km}$ & 1 year \\
\hline & Sea salt & Black carbon & (Mesoscale) & \\
\hline & Volcanic dust & Organic aerosol & & \\
\hline & Biological debris & Sulfates from $\mathrm{SO} 2$ & & \\
\hline & $\begin{array}{l}\text { Sulphates from } \\
\text { DMS } \\
\text { Sulphates from } \\
\text { volcanic } \mathrm{SO}_{2}\end{array}$ & Nitrates from NOx & & \\
\hline & $\begin{array}{l}\text { Organic aerosol } \\
\text { from biogenic } \\
\text { VOC }\end{array}$ & & & \\
\hline
\end{tabular}

Citation details: Mouzourides, P., Kumar, P., Neophytou M.K., 2015. Assessment of long-term measurements of particulate matter and gaseous pollutants in South-East Mediterranean. Atmospheric Environment 107, 148-165. [Online link] 
Table S3: The atmospheric stability classes, based on meteorological conditions (Pasquill, 1961).

\begin{tabular}{|c|c|c|c|c|}
\hline \multirow[b]{3}{*}{$\begin{array}{c}\text { Wind speed at } \\
10 \mathrm{~m}(\mathrm{~m} / \mathrm{s})\end{array}$} & \multicolumn{4}{|l|}{ Daytime } \\
\hline & \multicolumn{3}{|c|}{ Incoming solar radiation $\left(\mathrm{W} / \mathrm{m}^{2}\right)$} & \multirow{2}{*}{$\begin{array}{l}\text { Night } \\
\text { time }\end{array}$} \\
\hline & $\begin{array}{l}\text { Strong } \\
(>600)\end{array}$ & $\begin{array}{l}\text { Moderate } \\
(300-600)\end{array}$ & $\begin{array}{l}\text { Slight } \\
(150-300)\end{array}$ & \\
\hline$<2$ & $\begin{array}{l}\text { Very } \\
\text { unstable }\end{array}$ & $\begin{array}{l}\text { Very } \\
\text { unstable }\end{array}$ & Unstable & $\begin{array}{l}\text { Very } \\
\text { stable }\end{array}$ \\
\hline $2-3$ & $\begin{array}{l}\text { Very } \\
\text { unstable }\end{array}$ & Unstable & $\begin{array}{l}\text { Slightly } \\
\text { unstable }\end{array}$ & Stable \\
\hline $3-5$ & Unstable & Unstable & $\begin{array}{l}\text { Slightly } \\
\text { unstable }\end{array}$ & Neutral \\
\hline $5-6$ & $\begin{array}{l}\text { Slightly } \\
\text { unstable }\end{array}$ & $\begin{array}{l}\text { Slightly } \\
\text { unstable }\end{array}$ & Neutral & Neutral \\
\hline$>6$ & $\begin{array}{l}\text { Slightly } \\
\text { unstable }\end{array}$ & Neutral & Neutral & Neutral \\
\hline
\end{tabular}

Citation details: Mouzourides, P., Kumar, P., Neophytou M.K., 2015. Assessment of long-term measurements of particulate matter and gaseous pollutants in South-East Mediterranean. Atmospheric Environment 107, 148-165. [Online link] 